


\section{Kansen voor meer groenten en fruit in zorginstellingen}

Marieke J.G. Meeusen, Emily Bouwman, Victor Immink, Siet Sijtsema 
Meeusen, M.J.G., E. Bouwman, V. Immink, S.J. Sijtsema, 2016. Kansen voor meer groenten en fruit in zorginstellingen. Wageningen, Wageningen Economic Research, Rapport 2016-089. 54 blz.; 1 fig.; 0 tab.; 60 ref.

Dit rapport verkent de mogelijkheden om de inname van groenten en fruit in zorginstellingen te verhogen. Met aanvullend de vraag of (i) de biologische variant en/of (ii) de regionale herkomst meerwaarde biedt. Er zijn mogelijkheden om de consumptie van groenten en fruit te vergroten, vooral wanneer er meerdere eetmomenten ontwikkeld worden. Producten uit de streek bieden meerwaarde vanwege de (verse) smaak en leiden ertoe dat de zorginstellingen goed ingebed raken in de regionale economie.

This report explores the possibilities to increase the consumption of vegetables and fruit at care institutions. In addition, the question of whether (i) organic varieties and/or (ii) regional products provide added value will be addressed. There are possibilities to increase the number of fruit and vegetables consumed, especially when multiple meal times are developed. Regional products have added value because of their fresh taste, and ensure that care institutions become embedded in the regional economy.

Trefwoorden: ouderen, zorginstellingen, voeding, groenten en fruit, streekproducten, biologische producten.

Dit rapport is gratis te downloaden op http://dx.doi.org/10.18174/394442 of op www.wur.nl/economic-research (onder Wageningen Economic Research publicaties).

(C) 2016 Wageningen Economic Research

Postbus 29703, 2502 LS Den Haag, T 07033583 30, E communications.ssg@wur.nl, www. wur.nl/economic-research. Wageningen Economic Research is onderdeel van Wageningen University \& Research.

\section{(cc) BY-NC}

Wageningen Economic Research hanteert voor haar rapporten een Creative Commons Naamsvermelding 3.0 Nederland licentie.

(C) Wageningen Economic Research, onderdeel van Stichting Wageningen Research, 2016 De gebruiker mag het werk kopiëren, verspreiden en doorgeven en afgeleide werken maken. Materiaal van derden waarvan in het werk gebruik is gemaakt en waarop intellectuele eigendomsrechten berusten, mogen niet zonder voorafgaande toestemming van derden gebruikt worden. De gebruiker dient bij het werk de door de maker of de licentiegever aangegeven naam te vermelden, maar niet zodanig dat de indruk gewekt wordt dat zij daarmee instemmen met het werk van de gebruiker of het gebruik van het werk. De gebruiker mag het werk niet voor commerciële doeleinden gebruiken.

Wageningen Economic Research aanvaardt geen aansprakelijkheid voor eventuele schade voortvloeiend uit het gebruik van de resultaten van dit onderzoek of de toepassing van de adviezen.

Wageningen Economic Research is ISO 9001:2008 gecertificeerd.

Wageningen Economic Research Rapport 2016-089 | Projectcode 2282100101

Foto omslag: Shutterstock 


\section{Inhoud}

Woord vooraf $\quad 5$

$\begin{array}{ll}\text { Samenvatting } & 6\end{array}$

S.1 Kansen voor meer groente en fruit in zorginstellingen $\quad 6$

S.2 Ondanks belang, onvoldoende consumptie $\quad 6$

$\begin{array}{lll}\mathrm{S} .3 \text { Methode } & 7\end{array}$

$\begin{array}{ll}\text { Summary } & 8\end{array}$

S.1 Possibilities for increased fruit and vegetables in care institutions $\quad 8$

S.2 Insufficient consumption despite interest $\quad 8$

$\begin{array}{ll}\text { S.3 Method } & 9\end{array}$

1

$\begin{array}{lr}\text { Aanleiding } & 10\end{array}$

2

Eetgedrag van ouderen

2.1 Aantal ouderen neemt toe 12

2.2 Ondervoeding $\quad 12$

2.3 Gezondheidsproblemen bij ondervoeding 13

2.4 'Gezonde voeding belangrijk' 13

2.5 Ouderen eten onvoldoende groenten en fruit $\quad 14$

$\begin{array}{llr}3 & \text { Eten in zorginstellingen } & 16\end{array}$

3.1 Veel veranderingen 16

3.2 Cliënten kwetsbaar voor ondervoeding 16

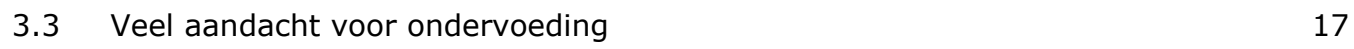

3.4 Voeding draagt ook bij aanwelbevinden en welzijn 18

3.5 Zorginstellingen hebben weinig (extra) aandacht voor groenten en fruit 20

$\begin{array}{lll}4.1 & \text { Beïnvloeden eet-omgeving } & 22\end{array}$

4.2 Productomgeving: portiegrootte en beschikbaarheid verhogen consumptie 23

4.3 Fysieke omgeving: ambiance verhoogt consumptie 23

4.4 Sociale omgeving: eten in gezelschap verhoogt de consumptie 24

$5 \quad$ Meer groenten en fruit? $\quad 26$

$\begin{array}{lll}5.1 & \text { Inleiding } & 26\end{array}$

5.2 'Veel en verse groenten en fruit zijn belangrijk' 26

5.3 Meer groenten? $\quad 27$

5.4 Mogelijkheden om meer groenten aan te bieden $\quad 29$

$\begin{array}{ll}5.5 & \text { Meer fruit? } \\ 5.6 & 29\end{array}$

5.6 Mogelijkheden om meer fruit aan te bieden 30

5.7 Kok, keukenpersoneel en budget essentieel 30

$6 \quad$ Biologische producten uit de regio $\quad 31$

6.1 Inleiding 31

6.2 Voorwaarde: lange adem en veel enthousiasme 31

6.3 Interventies bij Stichting Vrijwaard en Stichting Omring 33

6.4 'Regionale herkomst niet zo belangrijk' 33

6.5 Weinig kennis over regionale herkomst maaltijd 33 
6.6 'Smaak en het regionale aspect het belangrijkst' 34

6.7 Meer producten uit de regio vanwege de regionale inbedding en leefbaarheid 35

6.8 Meerwaarde van biologische herkomst lijkt beperkt 35

6.9 Kok, keten en voedingsassistenten essentieel 36

$7 \quad$ Conclusies en aanbevelingen $\quad 37$

$\begin{array}{lll}7.1 & \text { Conclusies } & 37\end{array}$

$\begin{array}{lll}7.2 & \text { Aanbevelingen } & 38\end{array}$

$\begin{array}{ll}\text { Literatuur en websites } & 39\end{array}$

$\begin{array}{lll}\text { Bijlage } 1 & \text { Stichting Vrijwaard en Stichting Omring } & 43\end{array}$

$\begin{array}{lll}\text { Bijlage } 2 & \text { Toelichting op de activiteiten } & 44\end{array}$

Bijlage 3 Belang elementen warme maaltijd 46

$\begin{array}{lll}\text { Bijlage } 4 & \text { Tabellen } & 47\end{array}$ 


\section{Woord vooraf}

In dit rapport worden de mogelijkheden verkend om de consumptie van groenten en fruit van bewoners in zorginstellingen te verhogen. Ook wordt de vraag beantwoord of groenten en fruit uit de regio en van biologische herkomst meerwaarde biedt. Er liggen kansen om meer groenten en fruit af te zetten in zorginstellingen vooral wanneer zij meerdere eetmomenten ontwikkelen. Producten uit de streek bieden meerwaarde vanwege de (verse) smaak en leiden ertoe dat de zorginstellingen goed ingebed raken in de regionale economie.

Dit onderzoek is onderdeel van een Publiek Private Samenwerking waarin zowel zorginstellingen als leveranciers van groenten en fruit deelnemen, binnen de topsector Tuinbouw\&Uitgangsmaterialen.

Wij willen de betrokken partijen uit het bedrijfsleven, Greenport Noord-Holland Noord, BD-totaal, Odin-Estafette en Royal Wessanen, en ook het ministerie van Economische Zaken bedanken voor de financiële bijdrage die het mogelijk heeft gemaakt deze opdracht uit te voeren.

We zijn ook alle inwoners van Stichting Vrijwaard en Stichting Omring dankbaar voor de medewerking aan het onderzoek. Ook de medewerkers bij de genoemde stichtingen zijn we erkentelijk voor hun tijd en inzet: Met name noemen we Grietje de Vries, Ivar Borst en Ruud Jekkers van Stichting Vrijwaard en Maarten van Dijk van Stichting Omring. Zij hebben het mogelijk gemaakt zoveel bewoners te kunnen vragen naar hun beleving van de warme maaltijd. We willen ook collega Machiel Reinders bedanken vanwege de waardevolle suggesties die hij als reviewer heeft gedaan. Tot slot willen we Renate Meeusen, Claudia Meeusen en Iris Jong bedanken voor hun rustige en zorgvuldige wijze van enquêteren onder de bewoners.

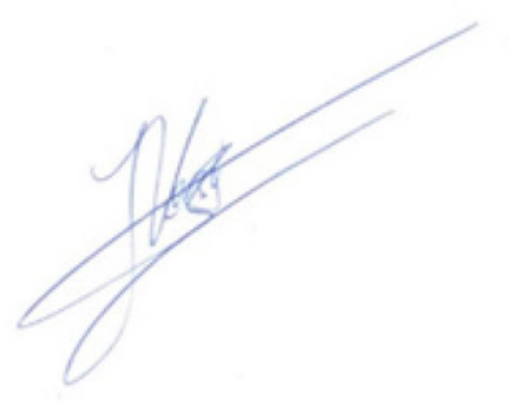

Prof.dr.ir. Jack (J.G.A.J.) van der Vorst Algemeen Directeur Social Sciences Group Wageningen University \& Research 


\section{Samenvatting}

\section{S.1 Kansen voor meer groente en fruit in zorginstellingen}

Er zijn kansen voor meer groente- en fruitconsumptie in zorginstellingen. De uitstraling van groenten en fruit op het bord versterkt de eetlust, terwijl juist een gebrek aan eetlust een belangrijke belemmering is om te eten. Ook leidt de aanwezigheid van groente ertoe dat cliënten de maaltijd lekkerder vinden en dat de maaltijd 'er mooier uitziet'.

Het onderzoek is uitgevoerd in opdracht van Greenport Noord-Holland Noord - als koepelorganisatie voor producenten van groente en fruit -, deelnemende leveranciers van biologische groenten en fruit (BD-totaal, Odin-Estafette en Royal Wessanen) en zorginstellingen.

Om de kansen voor meer consumptie te benutten moet rekening gehouden worden met specifieke kenmerken bij deze groep consumenten. De consumptie van (meer) groente en fruit wordt beperkt door een algeheel gebrek aan eetlust, kauw- en slikproblemen. Dit vraagt het op maat aanbieden van groenten en fruit (geschild, gesneden). Dit is ook het meest effectief om het risico van te veel groenten en dus voedselverspilling te voorkomen. Voedselverspilling zou het draagvlak bij de medewerkers van de zorginstelling voor 'meer groenten aanbieden' sterk verminderen. Er liggen vooral kansen voor groenten en fruit op meerdere eetmomenten: meer tussendoortjes

Groenten en fruit uit de regio biedt ook meerwaarde. Voor de zorginstellingen zelf bieden regionale producten de mogelijkheid om verbinding te zoeken met (potentiele) klanten en de regionale inbedding te vergroten. Bovendien is de maaltijd lekkerder en verser. Aandachtspunt daarbij is dat de organisatie van regionale ketens tijd, inzet en geduld vraagt. Ook kunnen er meerkosten zijn, zeker wanneer alleen gekeken wordt naar de kosten van de voeding. Wanneer echter alle positieve effecten van regionale producten worden meegenomen wegen de meerkosten op tegen de meeropbrengsten. Om de kennis over regionale producten bij cliënten te verhogen is communicatie - op verschillende manieren - nodig. Bovendien moet dit herhaaldelijk en veelvuldig gebeuren.

De kansen voor biologische groenten en fruit zijn minder groot. De hogere prijs vormt een belemmering en cliënten vragen nauwelijks om biologische producten.

\section{S.2 Ondanks belang, onvoldoende consumptie}

In zorginstellingen is voeding belangrijk voor de fysieke gezondheid van cliënten én vanwege de sociaal-culturele functie en daarmee het welbevinden van cliënten. Ouderen zelf vinden gezonde voeding ook belangrijk, maar ze eten niet voldoende groenten en fruit - ook niet in zorginstellingen. Zorginstellingen kunnen door interventies in product-, fysieke en sociale omgeving de consumptie van groenten en fruit stimuleren. Cliënten zeggen meer groenten en fruit te willen en komen zelf met suggesties die aansluiten bij de richtlijnen om cliënten zodanig voeding aan te bieden die passen bij hun fysieke behoeften. 


\section{S.3 Methode}

De vraag 'Hoe kan de consumptie van groenten en fruit in zorginstellingen verhoogd worden?' is beantwoord door literatuuronderzoek en praktijkonderzoek bij twee zorginstellingen. Beide organisaties zijn bezig met aanpassingen in het voedingsconcept. $\mathrm{Zij}$ willen het verbeteren voor hun cliënten en zij willen de verspilling terugdringen. Daarbij kiezen ze voor verschillende interventies, waarbij beiden het element 'regionale herkomst' inbouwen. Er zijn verschillende activiteiten uitgevoerd bij de twee zorginstellingen, namelijk:

- een enquête onder de cliënten bij de twee zorginstellingen zelf

- een interview met het management rondom voeding bij de twee zorginstellingen

- een focusgroep met medewerkers van de Voedingsdienst van Stichting Vrijwaard en twee interviews met medewerkers van de Voedingsdienst van Stichting Omring. 


\section{Summary}

\section{S.1 Possibilities for increased fruit and vegetables in care institutions}

There are several possibilities for increased fruit and vegetable consumption in care institutions. The bright colours of fruit and vegetables on a plate improve appetite. This counters a lack of appetite, which often leads to undereating. The presence of vegetables on the plate also helps clients to enjoy the meal more and they note that it makes the meal look more appetising as well.

This research was conducted on behalf of Greenport Noord-Holland Noord as the umbrella organisation for fruit and vegetable producers, participating suppliers of organic fruit and vegetables (BD-totaal, Odin-Estafette and Royal Wessanen) and care institutions.

In order to capitalise on the opportunities to increase consumption, the specific characteristics of this group of consumers needs to be taken into account. The increased consumption of fruit and vegetables is inhibited by a general lack of appetite and difficulty with chewing and swallowing. This requires personalised servings of fruit and vegetables (peeled, cut). This is the most effective approach to preventing excessive portions of fruit and vegetables being served and thus reduces food waste as well. Increased food waste would also strongly reduce the support of the staff at the care institutions for providing more fruit and vegetables. The possibilities to increase fruit and vegetable consumption are especially found in the introduction of more snacks between meals.

Regionally produced fruit and vegetables also have added value. Using local products provides care institutions with the opportunity to connect to potential clients and to embed the institution in the region itself. Furthermore, these products make the meal fresher and more appetising. It must be noted, however, that the organisation of regional chains requires time, effort and patience. It can also incur additional costs, especially when only the cost of the food is considered. However, when considering all the positive effects of regional products, the expenses are compensated by the returns. Different types of communication are needed to improve the knowledge of clients about regional products. Moreover, this communication needs be repeated often.

The opportunities for organic fruit and vegetables are somewhat less. Their higher cost is an impediment and clients rarely request organic products.

\section{S.2 Insufficient consumption despite interest}

Diet and nutrition is highly important in care institutions in the way it supports the physical health of clients, and also has an important socio-cultural function that improves the well-being of clients. The elderly are of the opinion that healthy food is important but do not eat sufficient fruit and vegetables even at the care institutions. Care institutions are able to stimulate the consumption of fruit and vegetables through interventions in products and the physical and social environment. Clients report wanting to eat more fruit and vegetables and have provided suggestions that fit the guidelines for providing clients with a diet that suits their physical needs. 


\section{S.3 Method}

A literature survey and practical research at two care institutions have answered the question, 'How can the consumption of fruit and vegetables in care institutions be increased?'. Both organisations are currently making changes to their diet and nutrition concepts. These organisations want to improve the diet and nutrition of their clients while also reducing food waste. They have opted for different kinds of interventions, but both organisations have included the 'regional origin' element in their new approach. The following activities were conducted at these two care institutions:

- a survey amongst clients at the two care institutions

- an interview with management about diet and nutrition at the two care institutions

- a focus group of employees from the food and nutrition services at Stichting Vrijwaard and two interviews with staff from the food and nutrition services at Stichting Omring. 


\section{$1 \quad$ Aanleiding}

PPS-partners willen mogelijkheden verkennen

Een hogere inname van groenten en fruit draagt bij aan de gezondheid van mensen. Dat geldt ook voor oudere mensen die hun maaltijd betrekken bij een zorginstelling. Steeds meer mensen verblijven korte of langere tijd in een zorginstelling. Deze instellingen willen hun cliënten goed verzorgen met oog voor de fysieke gezondheid, welbevinden en welzijn. In deze context willen Stichting Vrijwaard en Stichting Omring de mogelijkheden verkennen om meer groenten en fruit aan de cliënten aan te bieden.

Ze denken daarmee ook hun positie ten opzichte van andere zorginstellingen te versterken. Ook Greenport Noord-Holland Noord - als koepelorganisatie voor producenten van groenten en fruit - en deelnemende leveranciers van biologische groenten en fruit (BD-totaal, Odin-Estafette en Royal Wessanen) zijn geïnteresseerd in de mogelijkheden om meer groenten en fruit aan deze doelgroep aan te bieden. Zij willen bovendien weten of producten (i) van biologische herkomst en/of (ii) uit de regio 'extra waarde hebben voor de cliënten en zorginstellingen.

\section{Centrale vraag}

De centrale vraag van zowel de groente- en fruitbedrijven als zorginstellingen is dus: welke mogelijkheden zijn er om de inname van groenten en fruit in de gesloten setting 'zorginstelling' te verhogen. Met aanvullend de vraag of (i) de biologische variant en/of (ii) de regionale herkomst meerwaarde biedt.

Daartoe heeft Greenport Noord-Holland Noord samen met de deelnemende bedrijven een Publiek Private Samenwerkingsverband ${ }^{1}$ ontwikkeld waarin Wageningen Economic Research de mogelijkheden van meer consumptie van groenten en fruit door ouderen in zorginstellingen heeft verkend.

\section{Literatuuronderzoek en praktijkonderzoek}

\section{Praktijkonderzoek bij Stichting Vrijwaard en Stichting Omring}

De onderzoeksvraag is beantwoord aan de hand van literatuuronderzoek en praktijkonderzoek bij de zorginstellingen van Stichting Vrijwaard en Stichting Omring (zie bijlage 1). Beide organisaties zijn bezig met aanpassingen in het voedingsconcept. Zij willen het verbeteren voor hun cliënten en daarnaast verspilling terugdringen. Hierbij kiezen ze voor verschillende interventies, waarbij beiden het element 'regionale herkomst' inbouwen. Zij hebben in deze PPS ook specifieke - op hun interventie toegespitste - vragen gesteld.

Stichting Vrijwaard biedt haar cliënten sinds half mei 2015 een nieuw voedingsconcept waarin een aantal elementen rondom de warme maaltijd is veranderd. De menukeuze is beperkter maar beter passend bij de wensen van de cliënten, er komt meer voeding uit de regio en er wordt meer gewerkt met verse ingrediënten, wat ook wordt gecommuniceerd met de cliënten en er is meer aandacht voor de ambiance.

Bij Stichting Omring liep van 1 april tot 1 juli 2016 een pilot waarin één dag in de week een 'menu uit de streek' werd aangeboden, waarbij zo veel mogelijk ingrediënten uit de (Kop van) Noord-Holland zijn gebruikt. Niet alleen groenten en fruit, maar ook aardappelen, vlees en vis. Dit streekmenu werd aangeboden als keuzemenu. Men kon kiezen uit dit menu of een menu zonder streekelement en met andere ingrediënten.

\footnotetext{
${ }^{1}$ In deze PPS worden ook de mogelijkheden verkend om meer groenten en fruit in de kinderdagverblijven aan te bieden. Dit onderzoek is uitgevoerd door het Louis Bolk Instituut: van de Vijver et al. (2016).
} 


\section{Literatuuronderzoek, enquêtes, interviews en focusgroep}

$\mathrm{Na}$ het literatuuronderzoek zijn verschillende activiteiten uitgevoerd bij Stichting Vrijwaard en Stichting Omring, namelijk:

- een enquête onder de cliënten bij de twee zorginstellingen zelf

- een interview met het management rondom voeding bij de twee zorginstellingen

- één focusgroep met medewerkers van de Voedingsdienst van Stichting Vrijwaard en twee interviews met medewerkers van de Voedingsdienst van Stichting Omring

In tabel B4.1 is de focus en het doel per activiteit geformuleerd. Daaruit blijkt ook dat het vraagstuk om meer groenten en fruit aan te bieden, eventueel van regionale herkomst en/of biologisch, op verschillende manieren is benaderd. $\mathrm{Er}$ is gekeken naar wat:

- het management aan mogelijkheden, belemmeringen en oplossingen ziet

- de medewerkers in de Voedingsdienst in de praktijk tegenkomen en

- cliënten zelf ervaren.

Daarbij is in de enquête bij Stichting Omring gebruik gemaakt van de nieuwste inzichten van Wansink (2015) die de CAN-approach heeft ontwikkeld als een aanpak die inzichtelijk maakt waarom interventies wel of minder succesvol zijn. Hij beargumenteert dat de sleutel tot een effectieve voedingsinterventie niet ligt in het overtuigen van wat wel of niet gezond is of in de wilskracht van mensen. In plaats daarvan kan gezond eten bevorderd worden door ervoor te zorgen dat gezond eten gemakkelijk (convenient), aantrekkelijk (attractive) en normaal (normal) is (CAN approach; Wansink, 2015). 


\section{Eetgedrag van ouderen}

\subsection{Aantal ouderen neemt toe}

Er wonen meer ouderen in de Nederlandse samenleving. Het CBS voorspelt dat het aantal 65-plussers van 2,7 miljoen in 2012 tot 4,7 miljoen in 2041 stijgt. 2041 zal ook het hoogtepunt zijn. Het aantal 65-plussers zal tot 2060 rond de 4,7 miljoen blijven bewegen (www.nationaalkompas. nl > Bevolking > Vergrijzing).

Daarbinnen zal vanaf 2025 de groep 80-plussers nog sterk toenemen; er is een zogeheten dubbele vergrijzing. In 2040, met een recordaantal 65-plussers, is één derde van de 65-plussers ouder dan 80 jaar. Dat aandeel was in 2012 nog een kwart (www. nationaalkompas. $\mathrm{nl}$ > Bevolking > Vergrijzing).

Van de groep 65-plussers is $56 \%$ vrouw. Onder de 80 -plussers is zelfs $65 \%$ vrouw. Dit komt door de hogere levensverwachting van vrouwen dan die van mannen. Mannen worden gemiddeld bijna 80 jaar en vrouwen ruim 83 jaar oud (CBS, 2012).

\subsection{Ondervoeding}

De Richtlijnen Goede Voeding zijn bedoeld voor gemiddelde, gezonde Nederlanders. Daarbij gelden voor specifieke doelgroepen, zoals ouderen, specifieke richtlijnen en aanbevelingen. Bij ouderen treden fysiologische veranderingen op. Ook verandert hun leefstijl en zijn er vaker ziekten en beperkingen aan de orde. De helft van de 65-plussers heeft één of meer chronische ziekten. Hun energiebehoefte wordt lager en hun behoefte aan vitamine D stijgt. Tegelijkertijd komt een tekort aan vitamine B12 vaak voor (Informatorium Voeding en Diëtetiek, 2016). Het Voedingscentrum (2016) wijst ook op de noodzaak om meer te drinken in verband met de teruglopende nierfunctie.

In de VoedingsConsumptiePeiling 2010-2012 onder ouderen (Ocke, 2013) is de consumptie van diverse voedingsmiddelen door de mensen van 70 jaar en ouder geïnventariseerd. Van deze groep mensen was één op de acht ondervoed. Er was gemiddeld genomen minder energie-inname dan wordt aanbevolen voor mensen met een gematigde activiteit. Ook is er onvoldoende eiwit-, koolhydratenevenals voedingsvezelinname. Van bepaalde vetzuren werd voldoende ingenomen, maar van anderen een tekort. Ouderen hadden vooral meer vitamine D nodig. Van de meeste voedingsmiddelen eten mannen meer dan vrouwen, maar vrouwen eten meer fruit, noten en drinken meer niet-alcoholische dranken. Let wel dat de mensen die deelnamen aan dit onderzoek gezonder waren met minder gebreken en beperkingen dan de gemiddelde Nederlander van 70 jaar en ouder.

Ondervoeding komt veel voor bij ouderen en ook bij ouderen in zorginstellingen (Halfens et al., 2016). Men spreekt van ondervoeding wanneer onvoldoende energie, eiwit en andere voedingsstoffen wordt ingenomen. Dat kan een gevolg zijn van verminderde eetlust (door ziekte, ouderdom, medicijnen) of slikproblemen of onvoldoende mondzorg. Ook verandert het verzadigingsmechanisme bij ouderen. Interne invloeden (het hebben van honger of dorst) worden minder snel opgemerkt. Bovendien worden geur en smaak anders ervaren, waardoor oudere mensen minder eten (Vilans, 2012).

In het Informatorium Voeding en Diëtetiek (2016) wordt er op gewezen dat de voedingstoestand van ouderen verschilt, afhankelijk van de manier waarop ze ouder worden. Er worden drie groepen onderscheiden. De eerste groep veroudert 'normaal' terwijl de tweede groep - vaak woonachtig in zorginstellingen - slechter is met meer gebreken en chronische ziekten en de derde groep juist beter en 'succesvol' veroudert. (Informatorium Voeding en Diëtetiek, 2016). 
Wat die tweede groep betreft wijst Voedingscentrum (2016) erop dat zij meer afhankelijk zijn van anderen voor hun voedselinname. De inname van essentiële vitamines en calcium blijkt bij ouderen in zorginstellingen beneden de aanbevolen dagelijkse hoeveelheden te liggen. Voedingscentrum (2016) stelt vast dat naarmate ouderen meer afhankelijk zijn van anderen voor hun voedselinname de kans dat ze onvoldoende binnen krijgen groter wordt. Het lijkt daarbij vooral om vitamine B6, B12 en vitamine D te gaan (Ministerie van Landbouw, Natuurbeheer en Visserij, 2010).

\subsection{Gezondheidsproblemen bij ondervoeding}

Bij veel gezondheidsproblemen onder ouderen speelt voeding een rol. 'Een gezond voedingspatroon in combinatie met een gezonde leefstijl kan de kans op verschillende (chronische) ziekten verminderen', aldus de Nota Voeding en Gezondheid (2008). Dat geldt volgens diezelfde Nota ook voor de fase waarin men al ziek is of zorg nodig heeft. Ook dan kan een gezond voedingspatroon bijdragen aan de gezondheid en dus kwaliteit van leven van de betrokkene.

Ondervoeding leidt tot minder spiermassa waardoor krachtverlies optreedt en mensen eerder vallen en botten breken. Hierbij speelt vooral eiwit een rol. Immers eiwitten zijn van groot belang voor de opbouw en werking van spieren en organen. Daarnaast leidt ondervoeding tot een slechtere conditie van de huid, waardoor de kans op doorliggen op de loer ligt. Ook zijn er meer complicaties bij ziekte. De herstelperiode neemt toe (Vilans, 2012).

Ondervoeding gaat daarmee ook gepaard met hogere (zorg)kosten. Immers men gaat vaker op bezoek bij de huisarts, moet langer - en met meer medicatie - verpleegd en verzorgd worden (Vilans, 2012).

\section{4 'Gezonde voeding belangrijk'}

Ouderen vinden gezonde voeding belangrijk, ervaren ook sociale steun en een redelijke mate van eigen effectiviteit, maar ze hebben weinig kennis

Visser en Dijkstra (2011b) hebben onder zelfstandig wonende ouderen jonger dan 80 jaar gevraagd naar het belang dat zij hechten aan gezonde voeding. Daarbij hebben ze ook gevraagd naar de factoren die volgens de Theorie van Planned Behaviour (Ajzen, 1991) voorspellers zijn voor de intentie: attitude, sociale steun en ervaren gedragscontrole. De intentie leidt vervolgens direct tot gedrag.

Ruim twee derde zegt veel tot zeer veel aandacht te schenken aan gezonde voeding. Mannen doen dat iets minder dan vrouwen en ook kiezen vrouwen iets vaker (bijna) altijd voor gezonde voedingsmiddelen.

De kennis over gezonde voeding op een schaal van 0 (zeer slechte kennis) tot 32 punten (zeer goede kennis) is echter beperkt, namelijk 13,2 tot 13,4; daarbij scoorden hoger opgeleiden hoger dan lager opgeleiden (Visser en Dijkstra, 2011b).

Ouderen willen vooral gezond eten omdat ze zich 'fit willen voelen' (51,4\%), vanwege hun huidige gezondheid $(49,4 \%)$ en in mindere mate noemen ze lichaamsgewicht $(39,0 \%)$ of 'voorkomen van ziekten in de toekomst' $(28,5 \%)$. Omwille van de smaak telt voor slechts $14,4 \%$ (Visser en Dijkstra, 2011b).

Men heeft ook een redelijk positieve houding ten aanzien van gezond eten. Op een schaal van -2 (zeer negatieve attitude) tot +2 (zeer positieve attitude) is de gemiddelde score van rond +1 redelijk positief te noemen. Daarbij speelde geslacht, leeftijd, opleiding of inkomen geen significante rol. Ouderen met een meer positieve houding aten ook vaker volgens de voedingsrichtlijnen (Visser en Dijkstra, 2011b). 
De mate waarin men sociale steun ervaart bij het gezond eten is matig positief. Op een schaal van -2 (zeer negatieve sociale steun) tot +2 (zeer positieve sociale steun ) is de gemiddelde score rond + 0,6 , waarmee het als matig positief beoordeeld kan worden. Ouderen met een laag of middel inkomen ervaarden de sociale steun iets hoger dan ouderen die een hoger inkomen genoten. Ouderen die zich door hun sociale omgeving gesteund voelden aten ook vaker zoals de voedingsrichtlijnen aanbevelen (Visser en Dijkstra, 2011b).

Men scoorde op ervaren gedragscontrole ten aanzien van gezond eten redelijk positief met een $+0,80$. Ook hier was de schaal -2 (zeer lage eigen effectiviteit) tot +2 (zeer hoge eigen effectiviteit), waarbij eigen effectiviteit staat voor 'de verwachting van mensen over de mate waarin ze in staat zijn uit te voeren wat ze zich voornemen' (Visser en Dijkstra, 2011b).

\section{Ouderen vinden zelf dat ze gezond eten}

Ook in het onderzoek dat Schuttelaar en Partners deed onder 305 consumenten van 55-75 jaar waarvan vrijwel iedereen ( $92 \%$ ) nog thuis woonde en zelf het eten klaarmaakte, is het belang van gezonde voeding gevraagd. Van de ondervraagden vond $95 \%$ dat hij of zij gezond at. De helft ging ook beter op de voeding letten naarmate men ouder wordt/werd; voor (bijna) de andere helft veranderde dat weinig (Ministerie van Landbouw, Natuurbeheer en Visserij, 2010). Dat beeld kwam ook uit het kwalitatief onderzoek onder 28 ouderen. Ook zij zeiden meer op hun voeding te letten dan vroeger. Gezondheidsklachten vormen daartoe vaak aanleiding, vooral onder de lagere sociale klasse. Zij denken na over veranderend (eet)gedrag wanneer de gezondheidsklachten zich aandienen; mensen in de hogere sociale klassen zijn meer proactief.

Mannen en ouderen met een lage opleiding zijn het meest kwetsbaar De ouderen zelf is ook gevraagd of ze denken te voldoen aan de richtlijnen. Voor visconsumptie schatten ze dat redelijk goed in. Echter, bijna $16 \%$ onderschat de eigen fruitconsumptie, terwijl bijna $19 \%$ de eigen groenteconsumptie juist overschat. Die misperceptie komt vooral voor bij mannen en ook ouderen die lager opgeleid zijn (Visser en Dijkstra, 2011a).

Ouderen met een lagere opleiding eten vaker niet wat de richtlijnen voorschrijven. Echter, dit is niet gerelateerd aan een lagere attitude, minder sociale steun of een lager ingeschatte eigen effectiviteit. Wellicht spelen andere factoren een rol, zoals minder kennis of andere specifieke belemmeringen (Visser en Dijkstra, 2011a).

Oudere vrouwen besteden meer aandacht aan gezonde voeding en kiezen ook vaker voor gezondere producten - vaker dan mannen. Dit is ook terug te zien in de mate waarin ze aan de (fruit-, groentenen vis)richtlijn voldoen (Visser en Dijkstra, 2011a).

\subsection{Ouderen eten onvoldoende groenten en fruit}

Bijna helft eet onvoldoende groenten, $70 \%$ onvoldoende fruit

Ouderen eten volgens het RIVM nog niet voldoende groenten en fruit. Bijna de helft van de ouderen eet niet conform de Richtlijnen Goede Voeding waar het gaat om groenten. Voor fruit geldt dat voor maar liefst $70 \%$.

CBS (2015) heeft een iets ander beeld over de mate waarin ouderen eten conform de Richtlijnen voor Gezonde Voeding. Ze stelt dat ouderen weliswaar beter scoorden dan de gemiddelde Nederlander waar het gaat om het eten van groenten en fruit, maar ook zij constateren dat het niet genoeg is.

Ouderen vinden groenten en fruit heel belangrijk in een gezond eetpatroon

Op de vraag wat een eetpatroon gezond maakt antwoordt maar liefst $72 \%$ 'veel groenten en fruit'. Deze factor staat bovenaan. Op de goede tweede plaats - met $64 \%$ - staat 'gebalanceerd eten'. Daarna komen vooral de 'niet te veel ingrediënten': 'niet te veel vet' (31\%), 'niet te veel vlees' (16\%), 'niet teveel zout' $(11 \%)$ en 'niet teveel suiker' $(8 \%)$ (Ministerie van Landbouw, Natuurbeheer en Visserij, 2010). 
In een kwalitatief onderzoek onder 28 consumenten bleek 'Hollandse kost' hoog te scoren bij gezonde voeding. Men heeft het beeld dat 'gewoon' aardappels, vlees en groenten gezond zijn. Daarbij moet gevarieerd en regelmatig gegeten worden (Ministerie van Landbouw, Natuurbeheer en Visserij, 2010). De voorkeur Hollandse kost duidt op het vasthouden van gewoonten. Ook Reinders et al. (2012) stellen vast dat ouderen die in een zorginstelling wonen veel waarde hechten aan eten dat ze kennen van vroeger, dat vertrouwd is. Ook blijkt 'vers' een indicator voor gezond te zijn. Verse groenten, rechtstreeks van het land zouden gezond zijn (Ministerie van Landbouw, Natuurbeheer en Visserij, 2010).

Actuele ziekten, gebrek aan eetlust en kauw- en slikproblemen belemmeren de consumptie van groenten en fruit in zorginstellingen (Maar liefst een kwart ervaart geen enkele belemmering om gezond te eten. Wanneer ze wel belemmeringen ervaren gaat het om: gewoonten ('gewoonten bepalen wat ik eet') $(23,8 \%)$, smaak ('het is niet altijd lekker') $(10,4 \%)$, alleen eten $(9,7 \%)$ of de prijs ('gezond eten is te duur') (7,8\%). (Visser en Dijkstra, 2011b)

Om de fruitrichtlijn te halen ervaart bijna een derde geen enkele belemmering. Bij degenen die wel belemmeringen ervaren gaat het om de prijs $(10,5 \%)$, het bewaarproces $(8,1 \%)$, het snelle bederven van fruit $(7,5 \%)$ of het gebruik van pesticiden $(6,5 \%)$. Vergelijkbare punten kwamen terug bij groenten. Daar weet ruim een derde geen enkele belemmering te noemen. En ook daar komen prijs $(8,2 \%)$, pesticiden $(6,3 \%)$, bewaarproces $(6,1 \%)$ terug. Daarnaast noemen ouderen een geringe eetlust $(10,3 \%)$ wanneer het gaat om groenten. (Visser en Dijkstra, 2011b)

De bovengenoemde aspecten zullen minder een rol spelen wanneer ouderen in zorginstellingen wonen. Immers, de aankoop, het bewaren en het bereiden wordt voor hen geregeld. Dat betekent dat er weinig belemmeringen voor het consumeren van groenten en fruit zijn specifiek in de zorginstellingen. Wél relevant is wat de groep oudste ouderen noemt: moeite met kauwen en gebrek aan eetlust.

De groep oudste ouderen in de steekproef noemden vaker 'moeite met kauwen' waar het gaat om de consumptie van groenten en fruit. Zij voldeden ook vaker niet aan de fruitrichtlijn. Tsakos (2010) en Ervin (2008) wijzen ook op het belang van een goed gebit om groenten en fruit te kunnen consumeren. Een lagere consumptie van groenten en fruit houdt direct verband met de staat van het gebit. Ook noemden de groep oudste ouderen vaker dat ze geen eetlust hadden. Ook zij aten vaker niet conform de voedingsrichtlijnen.

Dit beeld komt terug bij Halfens et al. (2016) die in de Landelijke Preventiemeting Zorgproblemen 2015 hebben geïnventariseerd in welke mate en waarom cliënten in zorginstellingen minder eten. Uit tabel B4.4 blijkt dat 5\% van de cliënten gedurende korte of langere tijd minder eet. Daarbij speelt een verminderde eetlust en een actuele ziekte de grootste rol. 


\section{Eten in zorginstellingen}

\subsection{Veel veranderingen}

Meer ouderen naar zorginstellingen

Woittiez (2009) voorspelt dat tot 2030 het aantal mensen dat in zorginstellingen woont met gemiddeld 1,2\% per jaar stijgt. Op 1 januari 2012 woonden ruim 112.000 personen van 65 jaar en ouder in een zorginstelling. Dit komt neer op $4 \%$ van alle 65 -plussers en $14 \%$ van de 80 -plussers.

\section{Ander overheidsbeleid en minder geld}

De langdurige zorg is in transitie met vele kabinetsmaatregelen en bezuinigingen. Ouderen wonen langer thuis en komen pas in een zorginstelling wanneer ze lichamelijk en/of geestelijk slechter zijn. Daarmee wordt hun zorgvraag complexer en worden de eisen aan het (opleidingsniveau van het) personeel hoger. De financiële cijfers op de korte termijn zijn weliswaar op orde, maar er is enige terughoudendheid waar het gaat om noodzakelijke investeringen die zorginstellingen zouden moeten doen. Denk daarbij aan investeringen in (andere) woonvormen, meer opleiding en moderne technologie. Werknemers in de zorg hebben te maken met krimpende formatie en toenemende eisen aan hun expertise. Cliënten blijven weliswaar positief over de zorgverleners, maar werknemers maken zich zorgen over hun toekomst, zo laat de Benchmark in de Zorg (Actiz, 2015) zien.

\section{Meer marktwerking, meer vraaggestuurd en cliënt centraal}

$\mathrm{Er}$ is meer marktwerking in de zorg; zorginstellingen positioneren zich naar hun (toekomstige) cliënten, laten aan (toekomstige) cliënten zien hoe ze scoren op allerlei indicatoren, willen zich onderscheiden ten opzichte van anderen. Die cliënten worden ook mondiger, stellen hogere eisen aan de zorg en zorginstellingen willen het hen (dan) ook goed naar de zin maken: oog voor welzijn en welbevinden wordt steeds belangrijker in de strijd om de cliënt (en hun familie, mantelzorger).

\subsection{Cliënten kwetsbaar voor ondervoeding}

Cliënt vaker laag opgeleid met een laag inkomen en veel gezondheidsproblemen Bewoners van verpleeg- en verzorgingstehuizen zijn gemiddeld 80 tot 85 jaar oud, vooral vrouw, laag opgeleid, met een laag inkomen en met veel beperkingen en chronische aandoeningen. Voorspellingen wijzen erop dat de ernst van beperkingen en de aanwezigheid van chronische aandoeningen gelijk blijven. Tegelijkertijd verandert de samenstelling van de bewoners: het aandeel vrouwen zal afnemen evenals het aantal verweduwden. Het aandeel samenwonenden zal ongeveer gelijk blijven. De verwachting is dat de bewoners van 2030 hoger opgeleid zijn en dat ook het inkomen hoger zal liggen (Woittiez, 2009).

Hogere kwetsbaarheid vanwege onvoldoende voedingsstoffen In het Informatorium Voeding en Diëtetiek (2016) komt ook de (hogere) kwetsbaarheid van ouderen in zorginstellingen terug.

Daar wordt een aantal indicatoren opgesomd dat een aanwijzing is voor extra kwetsbaarheid waar het gaat om niet-voldoende voedingsstoffen voorziening:

- lage energie-inname

- groot ongewild gewichtsverlies

- lage sociaaleconomische status

- sociale isolatie en eenzaamheid

- hoogbejaardheid

- mobiliteitsproblemen

- lichamelijke of verstandelijke beperkingen 
- verminderde subjectieve gezondheid, ziekte en geneesmiddelengebruik

- plotseling verandering van de leefsituatie

- verblijf in een verzorgings- of verpleegtehuis.

Veel van deze factoren zijn aan de orde bij ouderen in een zorginstelling. Extra aandacht voor voldoende voedingsstoffen is daarom nodig.

\subsection{Veel aandacht voor ondervoeding}

Ondervoeding op de agenda

Binnen instellingen zou één op de vier à vijf cliënten ondervoed zijn (Voedingscentrum, 2016). Er is volop aandacht voor ondervoeding in zorginstellingen. In 2006-2009 zijn veel zorginstellingen met voeding aan de slag gegaan en is het aanbod sterk verbeterd. Door alle maatregelen is bij de verpleeg- en verzorgingstehuizen het gewichtsverlies met $50 \%$ teruggelopen en de ondervoeding in verpleegtehuizen met $24 \%$ verminderd. Aandacht voor ondervoeding is ook verankerd in het beleid; het is een van de prestatie-indicatoren in de basisset voor ziekenhuizen en zorginstellingen.

Vilans (2012) beveelt aan goed te kijken naar de onderliggende oorzaken van ondervoeding en pas dan een daarbij passende interventie te organiseren. Naast medische handelingen gericht op betere mondzorg en het verhelpen dan wel omgaan met problemen bij slikken en kauwen komen zij met de volgende aanbevelingen:

- Vergroot de bewustwording en kennis over eten en drinken

- Inventariseer de wensen en behoeften

- Signaleer ondervoeding

- Verbeter de ambiance

- Organiseer samenwerking tussen 'zorg' en 'keuken'.

\section{Stuurgroep Ondervoeding met aanbevelingen}

De stuurgroep Ondervoeding (2016) komt met een lijst van aanbevelingen voor goede voedingsconcepten voor ziekenhuizen die ook toepasbaar zijn in verpleeghuizen, waarvan voor dit onderzoek de volgende het belangrijkst zijn:

- Het aanbieden van een onbeperkt aantal eetmomenten

- Gebruiksvriendelijke bestelprocedure

- Korte tijd (minder dan een uur) tussen bestellen en serveren

- Veel menu-opties

- Brood en broodbeleg ter plekke kiezen en serveren

- Aangepaste voeding voor speciale doelgroepen

Ze beschrijft de meest en minst ideale situatie voor verschillende elementen van het voedingsconcept. Een aantal daarvan is opgesomd in tabel B4.6. De mate waarin de meest optimale situatie al realiteit is, verschilt per aspect van 'niet nauwelijks geïmplementeerd' tot 'bijna overal al praktijk'. Duidelijk is dat er al veel is gebeurd maar dat er ook nog een weg te gaan is.

\section{En jaarlijkse monitoring in de Landelijke Prevalentiemeting Zorgproblemen}

De Landelijke Prevalentiemeting Zorgproblemen (LPZ) meet jaarlijks het voorkomen van een aantal zorgproblemen in de Nederlandse gezondheidszorg. Ondervoeding is één van de aandachtspunten die terugkomt. In 2015 meldt de LPZ dat één op de vijf bewoners te maken heeft met ondervoeding, waarbij het vooral bij bewoners in de kleinschalige woonvormen alsook bij de meerzorgafdelingen en bij de oudere cliënten voorkomt. LPZ ziet een stabiel beeld gedurende de afgelopen jaren (Halfens et al., 2016).

Omdat cliënten met ondervoeding meer zorg vragen is het rendabel om ondervoeding aan te pakken, volgens Kok et al. (2014). De onderzoekers hebben daarbij gekeken naar de inzet van medische voeding als behandelmethode en geen andere voedings-interventies als aanpak beoordeeld (Kok et al., 2014). 


\subsection{Voeding draagt ook bij aanwelbevinden en welzijn}

Voeding heeft ook een culturele functie

Eten en maaltijden hebben tot doel dat alle voor het lichaam noodzakelijke voedingsstoffen en energie aangeleverd worden. Echter, eten en maaltijden hebben niet alleen deze zogenaamde fysiologische functies; Jobse-van Putten (1995) noemt ook andere functies:

- de sociale of groepsonderscheidende functie

- de identiteitsfunctie

- de communicatiefunctie

- de machtsfunctie en

- de culinaire of genotsfunctie.

Deze niet-fysiologische functies behoren tot het terrein van de culturele functies: de functies op het terrein van het waarden- en normenstelsel. Ze zijn sterk met elkaar verbonden en dat niet altijd duidelijk is welke functie in welke context (vooral) aan de orde is.

Verschillende culturele functies van voeding

De sociale of groepsonderscheidende functie heeft betrekking op de verbinding die voedingsmiddelen of gerechten tot stand kunnen brengen binnen een groep. Het zijn gerechten of maaltijden die door alle groepsleden wordt gegeten en vaak verbonden aan de plaats op de sociale ladder.

De identiteitsfunctie heeft betrekking op de sociale, regionale, nationale of culturele gebondenheid van iemand die tot uiting komt in zijn of haar eetgewoonten. Zo eten Amerikaanse Hongaren nog steeds graag goulash. Men laat door zijn eetgewoonten zien dat men tot een bepaalde groep behoort en binnen die groep ontstaat een gevoel van saamhorigheid.

De communicatieve functie is verbonden aan het feit dat er ruimte is tijdens de maaltijden om met elkaar te communiceren, ervaringen (van de dag) uitwisselen, de onderlinge band kunt versterken. 'Samen eten is gezellig' is een veelgehoorde uitspraak. Samen eten draagt bij aan in stand houden van sociale relaties. Jobse-van Putten (1995) stelt zelfs dat het sociale element zin geeft aan eten en drinken. Het gaat verder dan 'alleen gezellig bij elkaar zijn', want het geeft ook culturele betekenis. Er worden normen en waarden gedeeld en doorgegeven: over het eten zelf en ook over normen op waarden op ter tafel komende (maatschappelijke) gespreksonderwerpen.

Bij de machtsfunctie van voedsel draait het om voedsel om gewenst gedrag te stimuleren of (bij voedselweigering) niet gewenst gedrag te veranderen.

Lekker eten betekent ook plezier, genieten en daarmee komen we op de culinaire of genotsfunctie.

En daarmee draagt voeding bij om het cliënten naar de zin te maken

De bovengenoemde niet-fysiologische functies van voeding kunnen de maaltijd tot aangrijpingspunt maken om de niet-lichamelijke gezondheid van cliënten te verbeteren. Zorginstellingen kunnen maaltijden aangrijpen om de sociale interactie tussen de bewoners te vergroten en de kwaliteit van leven te verbeteren. In dit verband wijst een aantal onderzoeken op de rol van samen eten in de zorginstellingen en worden de door Jobse-van Putten (1995) genoemde functies uitgewerkt en/of bevestigd.

\section{Maaltijd als ankerpunt}

Gezellige en sociale omgeving van maaltijden zou kunnen leiden tot meer gevoel van veiligheid, van 'doel in het leven', van ordening en regelmaat en structuur aan de dag en verhoging van de kwaliteit van het leven. Fjellstrőm et al. (2001) noemen de behoefte van mensen aan structuur en daarvoor is de maaltijd een prima ankerpunt. Immers, iedereen moet meerdere malen per dag eten. Die vaste plaats van eten in het leven heeft ook een cultureel element: het vormt normen, waarden en rituelen (ook) rondom eten. Er wordt veiligheid voor bewoners gecreëerd en dit draagt bij aan hun welzijn. Er wordt een gezamenlijk gevoel ontwikkeld over wat we wanneer 'moeten' eten, hoeveel we moeten 
eten. Maaltijden bieden de mogelijkheid 'to socialise' met de hulpverleners en de medebewoners van het tehuis.

Nijs et al. (2006) vonden dat verbetering van de sociale en fysische omgeving en sfeer een verdere verslechtering van de kwaliteit van leven tegenging. Dementerende ouderen werden minder bang, geïrriteerd en depressief. Gedurende zes maanden werden verschillende elementen veranderd:

- de aankleding van de tafel

- de bediening van de maaltijd

- de plaats en rol van de hulpverleners gedurende de maaltijd

- de door het tehuis bepaalde eetregels en

- eetregels gedurende de maaltijd.

Er werd gemeten welke effecten die had op:

- de kwaliteit van het leven

- de fysieke gesteldheid

- het lichaamsgewicht en

- de energie-inname.

Het waren vooral positieve effecten: de kwaliteit van het leven werd als 'hoger' ervaren, de fysieke gesteldheid stabiliseerde, evenals het gewicht. Dit bracht de onderzoekers tot de conclusie dat 'family style' maaltijden in verpleegtehuizen de kwaliteit van het leven positief beïnvloedt. Bovendien zeggen ze dat deze conclusie geldt voor alle (soorten) verpleegtehuizen.

Carrier et al. (2009) ontdekten dat (i) de keuze van de disgenoten evenals (ii) waar ze mogen eten de meest bepalende factor in kwaliteit van het leven is volgens de bewoners zelf. Ook het gevoel meer autonomie te hebben over het eetgedrag (de mogelijkheid om zelf iets tussendoor te pakken, om eten van bezoekende familieleden te kunnen consumeren) draagt bij aan de kwaliteit van het leven. Een aantal 'foodservice' factoren heeft ook invloed op de kwaliteit van het leven; denk daarbij aan de manier waarop het eten wordt opgediend. Dergelijke resultaten zijn door Carrier et al. (2009) gevonden evenals andere onderzoekers.

Curle en Keller (2009) zijn verder in het mechanisme van sociale interactie tussen ouderen die samen eten gedoken. Zij constateerden dat de maaltijd door ouderen wordt beleefd als 'een belangrijke sociale gebeurtenis' gedurende de dag. De maaltijd is een belangrijk moment om naar uit te kijken, dan komt de sociale interactie met anderen tot stand:

- er wordt met elkaar gepraat

Men groet elkaar, men praat over hoe men zich voelt, over het weer, over de mensen in het huis (de staf, de gasten) en over wat ze die dag hebben gedaan of gaan doen.

- het eten is onderwerp van gesprek hoe het smaakt, hoe het eruitziet en hoe warm of koud het is.

- men helpt elkaar men helpt elkaar om te zitten of te staan, helpt om obstakels weg te halen of

- helpt met het aanreiken van gewenste maaltijdcomponenten.

- er wordt ook advies over en weer gegeven wat het beste te doen in welke situatie. Daarbij gaat het ook om gezondheid en eten.

- men deelt met elkaar eten, persoonlijke eigendommen, maar ook dromen, angsten en spanning.

- men lacht met en om elkaar er worden grapjes gemaakt.

- er is ook non-verbaal contact lachen, oogcontact, knikgebaren etc.

Men waardeert elkaar via het verbale en non-verbale contact, maar er zijn ook minder positieve gevoelens: mensen worden afgewezen en genegeerd. 


\subsection{Zorginstellingen hebben weinig (extra) aandacht voor groenten en fruit}

Inkoop van (verse) AGF daalt

Uit bovenstaande blijkt dat er focus ligt op ondervoeding met haar tekorten aan energie en eiwit. Groenten en fruit lijken veel minder in beeld. Raynaud-Simon en Aussel (2012) schrijven over de 'bekende' wetenschap dat zorginstellingen vooral letten op kosten en logistiek en dat (daardoor) de kwaliteit van aangeboden groenten en fruit van ondergeschikt belang is. Dit wordt bevestigd door Vingerhoeds (2014) en onderstreept door de trends die Meeuwsen (2015) signaleert:

- De inkoopwaarde van aardappelen, groenten en fruit (AGF) bij zorginstellingen is dalende - een al jarenlang zichtbare trend.

- Terwijl AGF al een relatief klein deel (5\%) van de totale inkoopwaarde aan eten en drinken (1 miljard $€$ ) betreft, vergeleken met bijvoorbeeld bedrijven en restaurants. Daar staat de AGF in de top 3.

Binnen AGF gaat het vooral om groenten. De inkoopwaarde van groenten is 1,5 keer zo groot als die van fruit. Dit wordt vooral verklaard door de keuze voor voorverpakte producten. Er wordt relatief weinig vers product gekocht. Zeker in vergelijking met andere marktsegmenten. Een greep uit de meest voorkomende AGF-producten:

- Convenience verpakkingen worden vooral gekozen voor de groentenmixen, sla/ salade en fruitsalade.

- Veel instellingen kiezen voor diepvriesproducten, vooral peulvruchten komen uit de diepvries. Slechts $6 \%$ is vers.

- Ook is de zorg grootverbruiker van conserven, met name appelmoes.

- De zorginstellingen kiezen vooral voor knolgewassen, bladgroenten en koolsoorten (vergelijk met ziekenhuizen die vooral sla, groente/fruit salades, tomaten en komkommers kiezen). Bladgroenten nemen in populariteit af.

- Vers fruit betreft vooral citrusvruchten, appels, peren en banen.

Een lange weg te gaan

Hermens (2012) noemt een aantal belemmeringen voor meer groenten en fruit in de zorginstellingen:

- de prijs van voedingsmiddelen is vaak nog dé beslissende factor bij de aankoop ervan.

- voeding omvat nog geen $2 \%$ van de totale kosten. Uitgaande van een half miljard $€$ voor voeding op een budget van ruim 30 miljard euro in de intramurale zorg gaat het om 1,7\% van de kosten.

- voeding is 'geen sexy' onderwerp. Het heeft relatief weinig aandacht.

- er is geringe samenwerking tussen betrokken schakels als keuken, diëtisten en/of artsen. Ook Borgdorff (2011) heeft in haar focusgroepen met chefkoks en menu-verantwoordelijken binnen zorginstellingen geconcludeerd dat zorginstellingen vooral belemmeringen ervaren in het aanbieden van meer groenten en fruit. Ze zijn gefocust op efficiency en kostenbesparing. Van de Vijver (2014) noemt het gebrek aan motivatie en medewerking van het personeel evenals onvoldoende budget en personeelstekort als belangrijke belemmeringen.

Nog minder aandacht zou er zijn voor duurzaamheid of duurzaam inkopen. In 2012 zou dit niet hoog op de beleidsagenda's van zorginstellingen prijken. Hermens (2012) ziet vooral de invloed van individuele enthousiaste medewerkers of betrokken bestuurders. Hun enthousiasme is een voorwaarde voor succesvol implementeren en uitwerken van een (duurzaam) voedselbeleid.

Voorzichtige trend naar meer oog voor voeding

Als gezegd, zorginstellingen willen/moeten zich onderscheiden naar hun (toekomstige) cliënten in de race om de klandizie. Daarbij past ook een transparant beeld van wat die (toekomstige) cliënten ervaren en kunnen verwachten. Zorginstellingen maken steeds duidelijker aan hun (toekomstige) cliënten hoe zij scoren op allerlei indicatoren. Voeding is daar inmiddels één van. In de Benchmark in de zorg (Actiz, 2015) laten cliënten weten de maaltijd hoog te waarderen met een ruime 8 (variërend van een ruime 7 tot een ruime 8 ). Daarbij worden smaak en sfeer bij de maaltijden onderscheiden. Voeding wordt geleidelijk aan gezien als een manier om cliënten een plezierige tijd te bezorgen. 


\section{Daarbij bieden groenten en fruit meerwaarde}

Groenten en fruit bieden meerwaarde voor de cliënt. Raynaud-Simon en Aussel (2012) laten zien dat de kleurrijke uitstraling van groenten en fruit eetlust aanwakkert. Een gebrek aan eetlust is een van de meest genoemde belemmeringen om goed te eten (zie hoofdstuk 2). Daarnaast leveren groenten en fruit (uiteraard) micronutriënten, vezels en water. Dat laatste is van belang om het veelvoorkomende probleem van obstipatie te verminderen of zelfs te voorkomen. Dat zou de kwaliteit van leven verbeteren.

Meerdere manieren om groenten en fruit aan te bieden

- Groenten als onderdeel van de warme maaltijd waar bewoners een actieve rol in de bereiding spelen. Deze optie biedt de bewoners de mogelijkheid om actief te zijn, 'mee te doen'. Bovendien sluit het aan bij de wens van deze groep om aan hun gewoonten vast te houden. Raynaud-Simon en Aussel (2012) wijzen op de gewoonten van ouderen om veel groenten en fruit te eten (vergeleken met jonge mensen) en het kunnen vasthouden van die eetgewoonten zou de tevredenheid van deze mensen verhogen.

- Groenten en fruit als snack, waardoor

- extra eetmomenten ontwikkeld worden en dus

- extra momenten van sociale interactie en ook

- meer autonomie over het eetgedrag wordt ervaren.

Groenten en fruit uit de regio bieden bovendien de mogelijkheid om verhalen te (laten) vertellen, activiteiten te organiseren rondom groenten en fruit uit de regio - waarbij leveranciers zelf vertellen over hun producten. 


\section{$4 \quad$ Interventies in gesloten settings}

\subsection{Beïnvloeden eet-omgeving}

Drie typen omgeving

Reinders et al. (2012) hebben een model ontwikkeld dat laat zien hoe persoonskenmerken, productkenmerken en omgevingsinvloeden samen het keuzegedrag van consumenten binnen een gesloten setting beïnvloeden (zie figuur 4.1). Waar het gaat om de persoonskenmerken zijn de in hoofdstuk 2 genoemde kenmerken van ouderen relevant: verminderde eetlust, kauw- en slikproblemen, smaakverlies, slechtere gezondheid. Zorginstellingen kunnen veranderingen aanbrengen in vooral de drie verschillende typen omgeving, namelijk (i) de product-, (ii) de fysiekeen (iii) de sociale omgeving van consumenten. Veranderingen in deze omgeving kunnen de consumptie van voeding verhogen.

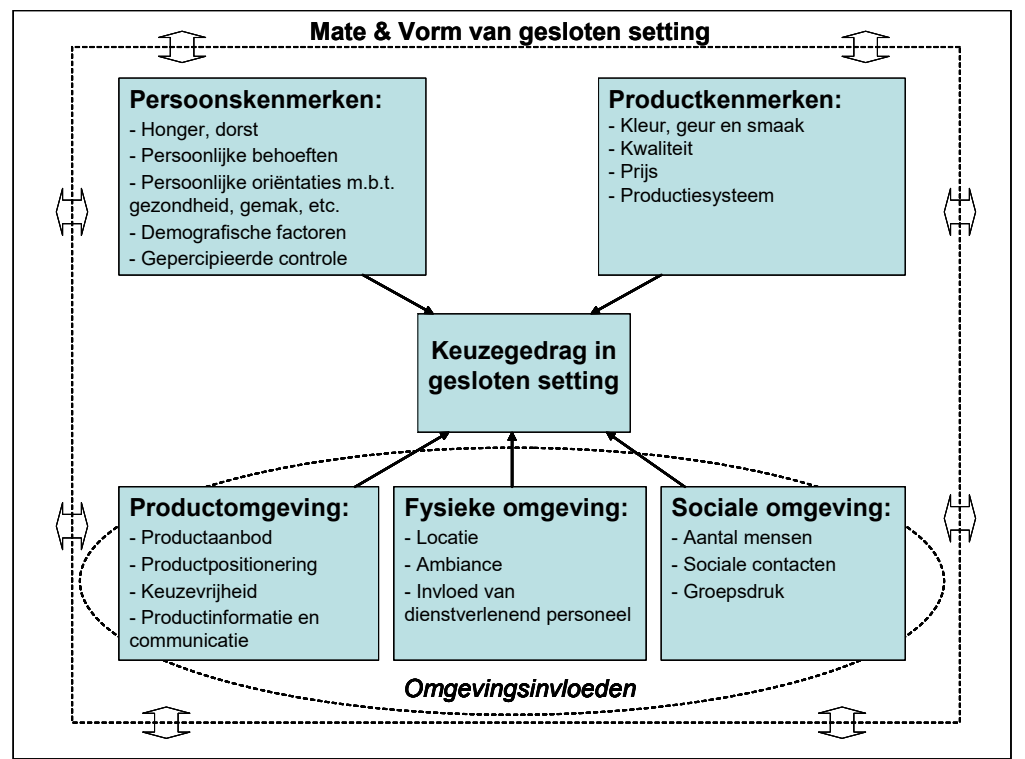

Figuur 4.1 Model voor bepaling keuzegedrag in gesloten settings (Reinders et al. 2012)

Er zijn weinig studies waarin de effecten van de verschillende interventies - in de verschillende bovengenoemde omgevingen - met elkaar vergeleken zijn. Ook is er weinig goed bewijs over de effectiviteit van interventies, ondanks de veelheid aan ontwikkelde en geïmplementeerde interventies.

\section{Overzichtsstudie}

Abbott et al. (2013) hebben in dit verband een interessante overzichtsstudie uitgevoerd. Zij hebben in een overzichtsartikel de ervaringen van interventies in zorginstellingen op een rij gezet. Zij starten het onderzoek vanuit de behoefte om meer te weten over de effectiviteit van de maaltijd-interventies. Welke interventie helpt om ondervoeding te verminderen? Gebaseerd op uiteindelijk 37 geselecteerde artikelen onderscheidden zij 5 typen interventies:

- andere productsamenstelling

- anders aanbieden en presenteren van de voeding

- andere eet-omgeving

- meer training van het personeel

- hulp met het eten. 
Daarmee hebben zij gekozen voor interventies in vooral de product- en fysieke omgeving. Het ging dus niet om voedingssupplementen. Bij de beoordeling van de impact werd gekeken naar de invloed van de interventie op (1) het gewicht van de cliënten en (2) de inname van voedsel.

\section{Interventies}

Interventies die vielen in de groep 'andere productsamenstelling' lieten tegenstrijdige resultaten zien. Waar de ene interventie geen effect vond, liet de andere interventie wel positieve resultaten op de inname van voeding zien. De effecten van interventies in de categorie 'food service' lieten een meer consistent beeld zien. Er werden vooral positieve effecten op de voedselconsumptie gevonden wanneer de maaltijden op manieren werden aangeboden die beter bij de cliënten wensen aansloten. Denk aan meerdere kleinere porties per dag in plaats of meer menu-keuzevrijheid. Interventies die de eet-omgeving veranderden hadden geen significant effect, al sprongen sommige interventies er positief uit. Ook lieten sommige interventies weliswaar geen toename van consumptie zien, maar rapporteerden cliënten wel een betere kwaliteit van leven. Training van personeel heeft positieve effecten; het aandeel cliënten met ondervoeding daalt. Ook hulp bij het eten heeft een positief effect.

Interventies leidden tot meer consumptie

Samenvattend, de onderzochte interventies leidden in het algemeen tot meer consumptie van voeding. Alle onderzochte interventies deden de consumptie verhogen met vooral interventies die een andere manier van aanbieden en presenteren van de maaltijd kozen en de interventies gericht op het aanbieden van hulp tijdens het eten. De extra voeding resulteerden echter niet altijd in minder gewichtsverlies. Overigens werden de studies niet als kwalitatief hoog beoordeeld. Abbott et al. (2013) pleitten daarom ook voor meer onderzoek op grotere schaal, met ook oog voor het socio-culturele aspect van voeding.

\subsection{Productomgeving: portiegrootte en beschikbaarheid verhogen consumptie}

Bij productomgeving noemen Reinders et al. (2012) productaanbod, waarbij zij keuzevrijheid, portiegrootte en speciale gelegenheden noemt. Het VoedingsCentrum (2016) benadrukt portiegrootte en beschikbaarheid.

Beschikbaar stellen van voedsel doet de inname stijgen. Wanneer mensen meer voedsel tot hun beschikking hebben eten ze er meer van. Dit in tegenstelling tot voedsel wat moeilijker beschikbaar is.

Zo krijgen mensen meer energie binnen als ze een groter portie krijgen aangeboden. Mensen kiezen vaak de middelmaat, ongeacht de hoeveelheid daarvan. De middelste maat wordt gezien als 'de normale' maat (Voedingscentrum, 2016). Ook bleek in de pilot van Genietende Tafel dat er meer groenten werden gegeten wanneer ze extra in bakjes op tafel stonden (Borgdorff, 2011). Dergelijke ervaringen zijn er ook in nog lopende onderzoeken naar interventies in een restaurant- en werkomgeving.

\subsection{Fysieke omgeving: ambiance verhoogt consumptie}

Reinders et al. (2012) noemen bij fysieke omgeving aspecten als locatie, ambiance en invloed van het dienstverlenende personeel. Het komt ook terug in de aanbevelingen die Stuurgroep Ondervoeding (zie hoofdstuk 3) heeft opgesteld en wordt nagevraagd in de tevredenheidsonderzoeken onder cliënten over de maaltijd (Actiz, 2015). Een greep uit enkele relevante studies.

Het gemiddelde gewicht van bewoners in een Bredaas verpleeghuis nam met 3,3 kilogram toe nadat de maaltijd gezelliger werd aangeboden. Bovendien bleef het welzijn van de bewoners 12 maanden op peil (Mathey, 2001). Abbott et al. (2013) hebben - als gezegd - ook meerdere interventies in de fysieke omgeving beoordeeld op hun effectiviteit en geconcludeerd dat zij hielpen om de consumptie te verhogen. 
In 2014 hebben Whear et al. gekeken naar de effecten van maaltijdinterventies op het gedrag van dementerende ouderen die in zorginstellingen wonen. Uit maar liefst 6118 artikelen hebben zij 11 artikelen geselecteerd die zij van voldoende niveau achtten. Deze artikelen beschreven vier groepen van maaltijd-interventies:

- zeven interventies waar muziek (gedurende de maaltijd) werd afgespeeld

- twee interventies die betrekking hadden op de omgeving gedurende de maaltijd

- één interventie waar de maaltijd anders werd opgediend en

- één interventie waar een conversatie een rol speelde.

De studies lieten allemaal enig effect zien op het gedrag van de dementerenden. Vooral de muzikale interventies lieten positieve effecten zien. In deze studies is geen uitspraak gedaan over de mate waarin cliënten meer of anders hebben gegeten.

\subsection{Sociale omgeving: eten in gezelschap verhoogt de consumptie}

Hermans (2015) vertelt over de diverse mechanismen in onze (sociale) omgeving die ons eetgedrag beïnvloeden. Allereerst beschrijft hij het fenomeen 'social facilitation'. Social Facilitation is het fenomeen dat menselijk (en dierlijk) gedrag onder invloed van andere mensen (en dieren) staat. Eetgedrag zou sterk beïnvloed worden door de sociale context. Met name De Castro $(1994,1995)$ heeft verschillende onderzoeken uitgevoerd. Ook Herman en Polivy (2005) wijzen op het effect van de sociale beïnvloeding. Zij stellen dat de invloed van de sociale norm zelfs groter is dan die van fysieke prikkels als honger en verzadigingsgraad.

Redd en De Castro (1992) zien het aantal mensen waarmee iemand eet als de beste voorspeller van de hoeveelheid voedsel die individuele mensen tot zich nemen. Daarbij maakt het weinig uit waar en wanneer de betreffende persoon eet en of het gaat om ontbijt, lunch, diner of snack: 'As the number of people eating with an individual increases, the amount of food consumed increases incrementally as a power function.' De Castro et al. (1992) constateerden ook dat wanneer mensen in gezelschap van één ander eten, er $28 \%$ meer wordt gegeten. Breidt het gezelschap zich uit naar twee mensen dan wordt $41 \%$ meer geconsumeerd oplopend naar $76 \%$ wanneer er samen met zes anderen wordt gegeten. Ook Lumeng en Hillman (2007) vonden een invloed van de grootte van de groep op voedselinname van kinderen. Jonge kinderen die samen met acht andere kinderen aten, consumeerden $30 \%$ meer voedsel dan kinderen die in gezelschap van twee andere kinderen aten. Ook voor mensen die verpleegd en verzorgd worden in instellingen geldt de regel 'zien eten doet eten'. Edwards and Hartwell (2004) vonden dat geïnstitutionaliseerde mensen die in gezelschap van anderen aten, meer aten dan mensen die alleen of alleen in bed aten. Ook noemen Paquet et al. (2008) studies die hebben uitgewezen dat mensen die samen met anderen in een gemeenschappelijke eetruimte hun maaltijd nuttigen meer eten dan degenen die dat niet doen. Paquet et al. (2008) hebben geconstateerd dat zowel diegene die de interactie met de ander uitzendt als diegene die het contact 'ontvangt' een hogere energie-opname laten zien dan mensen die minder interactie hebben met anderen.

Niet alleen de hoeveelheid van het geconsumeerde voedsel is onderhevig aan de sociale invloeden, ook heeft de sociale omgeving effect op de kwaliteit/samenstelling van het eten. Redd en De Castro (1992) laten ook zien dat aanwezigheid van disgenoten invloed heeft op wát er gegeten wordt. Curle en Keller (2009) die hun onderzoek richtten op ouderen die samen in het verzorgingstehuis hun maaltijd nuttigden, vonden dat disgenoten elkaar helpen bij het kiezen van gezonde voeding en elkaar stimuleerden om het gezonde te kiezen. Deze auteurs stellen dat 'social interaction can improve food intake'.

Er zijn twee factoren genoemd die dit proces zouden beïnvloeden:

- de aard van gezelschap en

- het eetgedrag van de disgenoten met de aanwezigheid van een leader. 
Wat betreft de aard van het gezelschap: wanneer gegeten wordt met bekenden is het fenomeen 'meer eten in gezelschap' duidelijker aanwezig dan wanneer er met vreemden wordt gegeten. Hermans (2015) wijst in dit verband ook op de rol van eten. Het speelt een rol in onze communicatie, identiteitsontwikkeling en genderrol. Paquet et al. (2008) constateren ook dat vooral 'communal' gedrag bijdraagt aan voedselinname. Dit betekent dat vooral het samen eten met bekende mensen meer bijdraagt aan voedselinname dan eten met onbekenden. De verklaring daarvoor wordt gevonden in het feit dat in een onbekende groep het element 'hoe kom ik over op (deze vreemde) anderen?' mee zou spelen. Dan is (te) veel eten minder passend. Mensen zouden dan minder snel geneigd zijn om (te) veel te eten. Immers dat zou niet getuigen van een gezonde levensstijl (King et al., 2004). (Te) veel eten in een sociale context zou duiden op onvoldoende zelfbeheersing, een lage mate van zelfcontrole en het niet kunnen weerstaan van verleidingen. Zo wil men zichzelf niet neerzetten in een groep onbekenden en dus worden calorierijke producten alleen in grote hoeveelheden gegeten wanneer de 'peer' of de 'leader' dat ook doet. Immers, dan is de schade minder groot. Grotere hoeveelheden gezonde, caloriearme groenten is minder 'not done'. We zijn minder bang dat het verorberen van dit type voedsel schade doet aan het beeld dat men in de groep wil neerzetten. 


\section{$5 \quad$ Meer groenten en fruit?}

\section{$5.1 \quad$ Inleiding}

De leveranciers van groenten en fruit vragen zich af of er meer afzetmogelijkheden liggen bij de zorginstellingen. Daartoe hebben we aan cliënten van Stichting Vrijwaard en Stichting Omring gevraagd hoe belangrijk zij groenten en fruit vinden, of zij meer groenten en fruit zouden willen eten en welke voorkeur zij voor eetmomenten en vorm hebben.

Drie enquêtes

- Enquête 1

Enquête onder 41 cliënten van Stichting Vrijwaard in augustus 2015

Doel van de enquête was antwoord te vinden op de vraag 'Hoe belangrijk vinden cliënten de verschillende elementen van het voedingsconcept?' en 'Hoe tevreden zijn ze daarover?'. Daarbij kwamen de verschillende factoren aan de orde die van belang zijn bij de waardering van voedsel, zoals smaak, gemak, gezondheid. Daarnaast is expliciet gevraagd naar elementen die veranderd zijn in het nieuwe concept, zoals herkomst, ambiance, variatie.

- Enquête 2

Enquête onder 25 cliënten van Stichting Omring in augustus 2015. Dit is dezelfde enquête als de bovengenoemde.

- Enquête 3

Enquête onder 92 cliënten van Stichting Omring in juni 2016. In deze enquête is de nadruk gelegd op:

- de wensen ten aanzien van groenten en fruit en

- de ervaringen met de interventie die Omring heeft uitgevoerd.

We hebben ook de medewerkers en het management rondom voeding gevraagd naar mogelijkheden en belemmeringen om meer groenten en fruit aan te bieden. Voor een verdere toelichting op de steekproef zie bijlage 2. Cliënten vinden veel en verse groenten en fruit belangrijk.

\section{2 'Veel en verse groenten en fruit zijn belangrijk'}

Veel en verse groenten en fruit belangrijk

Cliënten vinden veel en verse groenten belangrijk evenals vers fruit. Veel fruit bij de warme maaltijd vindt men minder belangrijk. Men waardeert ook andere (zuivel)desserts en eet fruit vaak buiten de warme maaltijd. In bijlage 3 staat het ervaren belang van meerdere items rondom de warme maaltijd op een rij.

\section{Tevredenheid}

Cliënten zijn ook tevreden over de hoeveelheid groenten en de versheid van groenten en fruit. Ook hier komen de redenen terug die hierboven zijn genoemd. Overigens zijn ze over het algemeen tevreden over hun warme maaltijd. De cliënten van Stichting Vrijwaard gaven de maaltijd gemiddeld 6,9 en de cliënten van Stichting Omring (waartoe Den Koogh behoort) gaven de warme maaltijd een 7,7 (juni 2016).

Geen verschillen tussen man en vrouw Er zijn geen significante verschillen gevonden tussen mannen en vrouwen.

Onduidelijke verschillen in leeftijdsgroepen

Er zijn geen eenduidige verschillen gevonden tussen leeftijdsgroepen. Voor Vrijwaard (2015) geldt: hoe ouder zijn hoe meer tevreden ze zijn over de hoeveelheid groenten en fruit. (Veel groente: 
Beta $=.424 ; p=.006-$ Veel fruit: Beta $=.342 ; p=.029)$. Bij de andere zorginstellingen is deze relatie niet gevonden.

Voor Den Koogh (2015) is de relatie 'hoe jonger mensen hoe meer belang zij hechten aan veel fruit bij de maaltijd' (Beta=-.501; $p=.002$ ) gevonden. Ook hier geldt: deze relatie is niet gevonden bij de andere zorginstellingen.

Veel groente smaakt lekkerder en ziet er beter uit

Uit de analyses van zowel Vrijwaard als Den Koogh (2015) blijkt dat hoe meer men het idee heeft dat er veel groente op het bord ligt, hoe meer zij de maaltijd ook lekker vinden smaken (Beta=.209; $p=.066$ ) en de maaltijd er goed uit vinden zien (Beta $=.252 ; p=.030$ ). Bij Omring in 2016 is dit verband niet gevonden. We zien een soortgelijk verband ook in hoofdstuk 3 terug: Raynaud-Simon en Aussel (2012) tonen aan dat de kleurrijke groenten en fruit eetlust aanwakkert.

\subsection{Meer groenten?}

Een kwart van de cliënten bij Stichting Omring zegt meer groenten te willen omdat het gezond en lekker is

Van de 91 ondervraagden in 2016 zegt $87 \%$ voldoende groenten te krijgen. Vijftien respondenten zeggen nóg meer groenten te willen. Ook 7 respondenten die zeggen onvoldoende groenten te krijgen willen meer groenten. Zij vinden dat zij minder groenten aangeboden krijgen dan degenen die niet meer groenten zeggen te willen. Op de vraag 'vindt u dat de warme maaltijd veel groenten bevat?' konden respondenten een score van 1-5 geven, waarbij 1 stond voor 'helemaal niet' en 5 stond voor 'helemaal wel'. Er bleek een significant verschil tussen beide groepen. De groep 'die meer groenten wil' scoorde 4,26, terwijl de groep die niet meer groenten hoeft 4,89 scoort. Een kwart van de respondenten zegt dus meer groenten te willen eten. $68 \%$ is tevreden met de aangeboden hoeveelheid op dit moment.

Gezond en lekker zijn de belangrijkste redenen om meer groenten te willen eten (tabel B4.10).

\section{Gebrek aan eetlust remt behoefte aan groenten}

Wanneer cliënten niet meer groenten willen is 'ik heb genoeg' veruit het meest genoemd. Hier komt dus de in hoofdstuk 2 genoemde (gebrek aan) eetlust terug.

\section{Meer groenten aanbieden?}

Toch is het de vraag of het feit dat bewoners zeggen meer groenten te willen eten moet worden vertaald naar 'bied meer groenten aan'. Enkele overwegingen. Allereerst is er de observatie van de Voedingsdienst van Stichting Omring dat er nog veel groenten terugkomt. Mogelijk is dit bij andere cliënten dan diegenen die aangeven meer groenten te willen, maar dat is niet duidelijk. ${ }^{2}$ Wél duidelijk is dat een gebrek aan tijd om alle groenten te eten niet de verklaring kan zijn voor het laten staan van de groenten. Zowel de interviewers als de bewoners zelf zeggen in de enquête dat ze tevreden zijn over de beschikbare tijd om (ongestoord) te kunnen eten.

Wil alleen de groep die niet zelf opschept meer groenten?

Wellicht dat mensen die niet zelf kunnen opscheppen onvoldoende groenten aangeboden krijgen. Daartoe is een aanvullende analyse uitgevoerd waarbij we onderscheid hebben gemaakt tussen mensen die zelf konden opscheppen en mensen die - na vooraf te hebben aangegeven hoe groot hun portie zou moeten zijn - hun eten opgeschept kregen. Echter, we vinden geen significant verschil. Het is dus niet zo dat vooral mensen die hun eten opgeschept krijgen meer groenten willen. Ook de mensen die zelf kunnen opscheppen willen meer groenten. Wellicht dat ze tóch een grotere drempel ervaren om meer groenten te pakken. De interviewers zien dat bewoners hun eten heel laagdrempelig

\footnotetext{
2 Respondenten konden alleen aangeven 'Ja, voldoende' of 'Nee, onvoldoende'. Ze konden niet aangeven 'Ja, zelfs te veel'. Door deze antwoordcategorie toe te voegen hadden we wellicht meer inzicht kunnen krijgen in het \% ouderen die de groenten niet op kunnen.
} 
en gemakkelijk voor hen aangeboden moeten krijgen. Wellicht dus dat de tafel iets te groot is of ze (te)veel tafelgenoten moeten vragen om de schaal door te geven?

Stichting Vrijwaard: cliënten willen niet méér groenten

Bij Stichting Vrijwaard kunnen mensen zelf kiezen voor een kleiner, normaal of groter portie. Heel weinig cliënten vragen om een groter portie. Alleen zieke mensen vragen minder. De indruk van de deelnemers aan de focusgroep bij de Stichting Vrijwaard is dan ook dat cliënten niet méér groenten willen.

Uit de verspillingscijfers van Stichting Vrijwaard blijkt dat er na de interventie die in 2015 is doorgevoerd minder weggegooid wordt, waaruit voorzichtig afgeleid kan worden dat cliënten ook meer groenten en fruit eten.

Stichting Vrijwaard meldde dat de voedselverspilling voor de interventie 34\% bedroeg en na de interventie (eind juli 2015) naar $15 \%$ was gedaald. Het aandeel groenten in de verspilling is gelijk gebleven (Diverzio, 2015). Howel de Stichting Vrijwaard dit verlies aan afval vooral toeschrijft aan de fase voorafgaand aan de uitservering is de indruk ook dat 'mensen beter hun bord leeg eten' omdat mensen het eten lekkerder vinden. Niet duidelijk is hoeveel dat is.

De deelnemers aan de focusgroep Vrijwaard geven herkenbare antwoorden en noemen spontaan dezelfde punten als de cliënten: smaak, versheid en gastvrijheid zijn goed op orde. Ze verwijzen naar opmerkingen die ze horen van cliënten, zoals 'Ik ben al 92 jaar, moet ik nóg langer leven?' of wanneer medewerkers wijzen op de gezondheid van groenten (en fruit): 'Zorg jij eerst zelf maar dat je zo oud wordt.' Ook zeggen ze het volgende:

- 'De porties zijn genoeg voor de mensen.'

- 'Als ik dit zou krijgen, zou ik ook tevreden zijn.'

- 'Mensen bewegen ook niet zo veel.'

- 'Om half tien krijgen ze koffie en dan om 12 uur alweer het eten.'

- 'Naar "groenten tussendoor" is geen vraag. Dat hoort ook niet bij deze generatie.'

Ook de geïnterviewde voedingsmanagers zien weinig vraag naar extra groenten. Ze wijzen op de moeilijk te veranderen gewoonten van de ouderen. Ze zijn al jaren gewend op een bepaalde manier te eten en het is moeilijk om dat patroon te doorbreken. En ook zij komen met uitspraken die ze van de cliënten horen:

- 'Ik ben al 92, dus ik ben gezond genoeg.'

- 'Ik ben al in de negentig en wil vooral lekker eten.'

- 'Ik ben al in de negentig, ga jij me nu vertellen wat gezond is?'

De deelnemers aan de focusgroep zeggen dat cliënten veel groenten en weinig aardappelen eten. De geïnterviewden denken daar anders over. Zij menen juist dat cliënten veel aardappelen en relatief weinig groenten eten. 'Dat zijn ze zo gewend, vanuit het arbeidsdenken en "op het land werken".'

En dan wil de Stichting Vrijwaard niet meer aanbieden

De Stichting Vrijwaard heeft de eigen regie, het zelfstandig zijn en blijven, het zelf invloed kunnen uitoefenen op de ondersteuning hoog in het vaandel staan. Daaruit komt voort dat cliënten zelf invloed hebben op de portiegrootte. Stichting Vrijwaard wil daar weinig sturend zijn. Dat maakt dat Stichting Vrijwaard de opties voor meer groenten en fruit aanbiedt, maar bij de cliënten zelf de keuze laat.

De deelnemers van de focusgroep Vrijwaard verwachten bovendien dat (stiekem) meer aanbieden van groenten leidt tot ongewenste effecten, waarbij ze noemen:

- Meer verspilling, 'anders moeten we het weggooien'. De medewerkers hadden voor de implementatiefase iets meer invloed om de portie te vergroten. Een half portie groenten leek zó weinig, dat het voor de medewerker 'zielig' overkwam. Er werd geen gebruik gemaakt van standaard portioneerlepels maar bijvoorbeeld van een schuimspaan. Dat droeg in de jaren bij aan verhoging van de verspilling, want wat niet geconsumeerd wordt belandt in de afvalbak. Om de voedselverspilling te verminderen zijn vanaf de implementatiefase standaard portioneerlepels in gebruik. 
- Meer druk en tegenzin bij cliënten, want dan kijken ze tegen een te vol bord aan 'en dat moet ik dan allemaal opeten' want 'een bord eet je leeg'.

Ook mantelzorgers van Stichting Vrijwaard vragen niet naar méér groenten en fruit Noch de geïnterviewden noch de deelnemers van de focusgroep ervaren een vraag van de mantelzorgers naar meer groenten en fruit voor de cliënten. Ze zeggen dat mantelzorgers niet eventueel namens de cliënten - vragen om extra groenten en fruit. Wel nemen ze zelf af en toe extra fruit mee. Daarbij kan het gaan om fruit dat geschild moet worden.

\subsection{Mogelijkheden om meer groenten aan te bieden}

Cliënten die bij Stichting Omring eten zijn gevraagd (i) op welk moment en (ii) in welke vorm zij het liefst groenten aangeboden krijgen (tabel B4.13).

Duidelijk blijkt de grote voorkeur voor de warme maaltijd als moment waarop meer groenten aangeboden zouden kunnen worden. Gekookte groenten, salades, rauwkost en soep worden het meest gewaardeerd. Deze voorkeuren sluit aan bij de gewoonten van ouderen, zie hoofdstuk 2 .

Variatie kan ten koste gaan van 'hoofdgroente'

Tegelijkertijd is hier een eerdere ervaring van Omring relevant. Wanneer teveel verschillende vormen van groenten bij de hoofdmaaltijd aangeboden worden, wordt minder van de 'hoofdgroente' gegeten. In het verleden bood men standaard iedere dag rauwkost en appelmoes aan, maar men zag dat deze groenten werden gegeten ten koste van de andere groenten. Daarom is nu gekozen voor integratie van deze producten in het hele gerecht. Bovendien: In het verleden bood men voorafgaand aan de hoofdmaaltijd soep aan, maar nu krijgen bewoners voorafgaand aan de broodmaaltijd soep. Door de soep waren bewoners te snel vol en bleef er minder ruimte voor groenten over.

De focusgroep van de Stichting Vrijwaard heeft nieuwe ideeën geformuleerd voor het aanbieden van (meer) groenten. Deze zijn in tabel B4.11 opgesomd.

De focusgroep houdt rekening met:

- bestaande gewoonten bij hun cliënten

- soep (positief)

- wraps, smoothies van groenten (laag)

- de aanwezigheid van kauw- en slikproblemen bij bepaalde cliënten

- smoothies van fruit; geraspt, geschild of zacht fruit (positief)

- de aaanwezigheid van andere fysieke gezondheidsproblemen bij cliënten

Verder denken ze dat producten uit de regio van bekende leveranciers positief gewaardeerd worden.

\subsection{Meer fruit?}

De helft van de cliënten bij Stichting Omring wil meer fruit omdat het gezond en lekker is Van de 89 respondenten in 2016 wil bijna 50\% meer fruit aangeboden krijgen. Weliswaar zegt $62 \%$ voldoende te krijgen aangeboden, maar toch zeggen velen meer fruit op prijs te stellen.

Ook bij fruit zijn gezond en lekker de belangrijkste redenen om er meer van te willen eten.

Ook bij fruit speelt een gebrek aan eetlust een rol

Ook hier komt 'ik heb genoeg' als belangrijkste reden om niet meer fruit te willen naar voren, al is het in mindere mate als bij groenten. Immers hier speelt ook het (al eerder genoemde) argument dat mensen zelf fruit kopen een rol.

De deelnemers aan de focus groups herkennen ook de behoefte aan meer fruit. 


\subsection{Mogelijkheden om meer fruit aan te bieden}

Vooral voorkeur voor het tussendoortje en dessert

Ook is gevraagd welke voorkeur er is wat fruit betreft (zie tabel B4.15). Fruit wordt vooral als tussendoortje en als dessert gevraagd, maar ook bij het ontbijt of bij de broodmaaltijd is een optie. Daarbij gaat de voorkeur uit naar stukjes fruit, vaak in geschilde en gesneden vorm. Fruitsap is een goede tweede; dat wordt vooral bij het ontbijt gewaardeerd, maar ook op andere (maaltijd)momenten van de dag.

Volop nieuwe ideeën

In de focusgroep bij Stichting Vrijwaard is een aantal nieuwe ideeën genoemd om (meer) groenten aan te bieden.

\subsection{Kok, keukenpersoneel en budget essentieel}

\section{Voorwaarden}

- De beschikbaarheid van extra (keuken)personeel. Dit geldt vooral voor de fruitproducten: cliënten stellen meer fruit op prijs wanneer het geschild en in stukjes gesneden wordt aangeboden. Echter, die tijd en capaciteit is er vaak niet. In de gesprekken kwam daarvoor als oplossing de inzet van vrijwilligers of andere goedkopere krachten (zoals HALT-mensen).

- Het enthousiasme van de kok om nieuwe ideeën uit te werken en te ontwikkelen, die liefde en plezier voor zijn (mooie, verse) producten heeft.

- Het enthousiasme van de distribuerende Voedingsdienst bij het aanbieden van de extra groenten en fruit bij cliënten. Zij moeten het 'verkooppraatje' houden voor wat wordt aangeboden. En de verwachting is dat wortelsap en broccoli-smoothies minder enthousiast worden aangeboden dan aardbeitjes.

- Het budget van de cliënten. Vers geperst sap in het restaurant vraagt een financiële bijdrage. Stichting Vrijwaard ervaart weinig animo in verband met de extra kosten voor de bewoners, die een laag inkomen en weinig financiële ruimte hebben. 


\section{$6 \quad$ Biologische producten uit de regio}

\section{$6.1 \quad$ Inleiding}

De leveranciers van groenten en fruit stellen zich ook de vraag of groenten en fruit uit de regio of van biologische herkomst meerwaarde heeft. Daartoe worden eerst enkele ervaringen met pilots en interventies elders in het land beschreven, waarna de ervaringen met de interventie en pilot bij Stichting Vrijwaard en Stichting Omring aan de orde komen. Overigens, vaak wordt gekozen voor biologische én streekgebonden producten, maar er zijn ook interventies waarbij alleen biologische producten of alleen producten uit de regio worden aangeboden. Voor een verdere toelichting op de steekproef zie bijlage 2 .

\subsection{Voorwaarde: lange adem en veel enthousiasme}

Anno 2013 werd nog gekopt dat duurzaam inkopen van voedsel nauwelijks een item is in de zorginstellingen. Toch ziet Meeuwsen in 2015 een beweging naar duurzaam voedsel, waarbij hij een toenemende vraag naar voedsel met bepaalde keurmerken noemt. Ook transparantie en verbinding met de regio signaleert hij als trend. Er duikt een aantal enthousiasmerende voorbeelden en pilots op in de zoektocht naar sprekende casussen: de Sint Maartenskliniek in Nijmegen, St Joris in Oirschot, het Zeeuwse Ter Reede, Insula Dei en Huize Kohlmann te Arnhem, Vivium Zorggroep Naarderheem, het initiatief De Genietende Groene Tafel of Een mooie maaltijd in Brabant. Allemaal komen ze met overwegend positieve verhalen. Tegelijkertijd wordt ook geschreven over de worsteling met kosten en logistieke processen. Overigens, vaak wordt gekozen voor biologische én streekgebonden producten, maar er zijn ook interventies waarbij alleen biologische producten of alleen producten uit de regio worden aangeboden.

Mensen herkennen en waarderen de streekproducten beter, en vinden die lekkerder en verser. Puur Culinair spreekt bijvoorbeeld over 'een feest van herkenning' (de Jong, 2012). Het zou ook goed passen in een beleid gericht op smaak, duurzaamheid en versheid.

Meer voedselinname, minder ondervoeding, verandering van ambiance en presenteren Het aanbieden van de regionale producten zou het welbevinden en spoedig herstel ten goede komen. De Genietende Groene Tafel liet minstens 60\% biologische producten uit de regio komen en veranderde ook elementen rondom beleving, zoals presentatie. Daar bleek dat er 32\% meer groenten gegeten werd (en het lichaamsgewicht met 0,6 kilogram steeg), al verbeterde de kwaliteit van leven evenals de mentale toestand niet significant (Halfens, et al., 2010). Boers (2012) laat zien dat de introductie van streekgebonden en biologische voeding in de woonzorgcentra Insula Dei en Huize Kohlmann (Arnhem) met tegelijkertijd meer aandacht voor ambiance het risico van ondervoeding en het gebruik van dieetproducten doet afnemen, al waren er geen significante veranderingen gemeten.

\section{Nauwelijks kostenstijging en wél besparing}

Hoewel de angst voor hogere kosten als gevolg van streekgebonden en/of biologisch een belangrijke hobbel is, ziet de directeur van Vivium Zorggroep Naarderheem na het gebruik van biologische producten uit de regio nauwelijks een kostenstijging. Hij meldt dat de biologische streekmaaltijd (slechts) 12 cent duurder is dan de gangbare. Daarbij wijst hij op vele (kosten besparende) gevolgen van de biologische maaltijd. Er worden (25\%) minder medicijnen gebruikt evenals minder dieetproducten. Vivium Zorggroep meldt ook dat er minder zorgpersoneel nodig is omdat mensen langer aan tafel zitten. Maar de grootste besparing vloeit voort uit het wegvallen van de menucyclus, waar vroeger een half jaar van te voren werd bepaald wat er nodig was en ingekocht moest worden kiest de kok nu twee dagen van te voren wat er gegeten en gekocht wordt (Raghoebar, 2011). 


\section{Kostenneutraal niet eenvoudig}

Om de kosten van streekmenu's en/of biologische producten beperkt te houden is oog voor de toeleverantie en de keten van groot belang. Het is niet eenvoudig om kostenneutraal te werken. Daartoe moet de leverantie van de voeding (ingrijpend) anders georganiseerd worden. Zowel Sint Maartenskliniek in Nijmegen als de St Joris in Oirschot zeggen binnen het voedingsbudget te kunnen blijven door creatief te zijn, waarbij ze noemen:

- Houd in de menucyclus rekening met de seizoenen.

- Verlaag het aandeel van de dure menucomponenten, zoals vlees.

\section{Schaalvoordelen}

Bundeling van krachten bij de inkoop gericht op schaalvoordelen (in plaats van levering door vele kleinere leveranciers) is wel van groot belang om de (meer)kosten beperkt te houden. Dat laatste gebeurt in Nijmegen door Oregional die de distributie regelt en de tussenhandel uitschakelt. De keten wordt ingekort met meer directe aanvoerlijnen en transparantie. Het belang van bundeling van aanbod wordt ook door Corstiaans van Puur Culinair benadrukt. Anders is het niet efficiënt en overzichtelijk (De Jong, 2012). Puur Culinair wijst ook op de grotere vrijheid van de zorginstelling wanneer ze spullen uit de streek halen. Bij de totaalleverancier - waar alles wordt ingekocht - is die vrijheid kleiner. Daar bepalen de (grote) leveranciers op basis van de prijs waar het product vandaan gehaald wordt. Daarmee hebben ze veel invloed op de menuplanning. Wanneer dit concept wordt losgelaten en zorginstellingen zelf hun leveranciers en hun producten kiezen komt die vrijheid weer terug. 'Producten uit de streek halen vergroot de keuzevrijheid' is daarom de overtuiging van Puur Culinair (de Jong, 2012). Het belang van logistiek en organisatie komt ook terug in het Zeeuwse initiatief in 2006-2007 en het daaropvolgende traject in één van de zorginstellingen, Ter Reede.

Ernst (2007) vatte een aantal ervaringen samen:

- Het aanbieden van biologische maaltijden vraagt veel inzet en betrokkenheid van alle partijen in de hele keten: van boer en groothandel tot en met de kok in de zorginstelling.

- Niet alle ingrediënten waren even gemakkelijk in de biologische variant te verkrijgen - ook in de gevraagde (grotere) hoeveelheden.

- (Daarom ook:) De kosten van de biologische maaltijden waren 30-35\% duurder dan de gangbare maaltijden. Diverse aanpassingen werden doorgevoerd om de prijs zo laag mogelijk te houden, maar toch lukte het niet om onder de $30 \%$ meerkosten uit te komen.

In 2011 werd nog een keer teruggekeken op het traject (Schoorel, 2011). De overwegingen om met biologische producten te werken zijn overeind gebleven. Hoofd Keuken zegt dat de smaak 'echt beter' is en hij ziet de biologische producten als aangrijpingspunt voor activiteiten met de mensen. Maar toch is het nog niet gelukt in de zorginstelling biologisch grootschalig aan te bieden. 'Het traject vergt tijd en veel overleg' zo kopt het artikel. De meerkosten die op het voedingsbudget drukken blijken een stevige hobbel. De logistiek en organisatie lijkt maatwerk te moeten zijn met een op maat ingerichte aanpak voor zowel zorginstellingen als handel, passend bij de (inkoop)contracten die er zijn. Dat betekent maatwerk in tijd, werkwijze en product. Hoe om te gaan met de (andere) inkoop is uitgewerkt in rekenvoorbeelden om de (over)stap te vergemakkelijken.

\section{Goede communicatie vereist}

Juist vanwege de kosten en de lange adem is het van groot belang om goed te communiceren: zowel intern als extern. Inmiddels is er al volop communicatie-materiaal, waarin ook diverse ervaringen zijn meegenomen. Zo heeft Ter Reede inmiddels de kennis opgedaan dat cliënten meer ontvankelijk lijken voor de boodschap dat biologisch lekkerder is waarbij 'de smaak van vroeger' wordt benadrukt. Dat biologisch gezonder zou zijn (want minder gewasbeschermingsmiddelen) werd niet gecommuniceerd. Wél werd het regionale aspect benadrukt. Dat sloeg ook aan. Bovendien werden er verschillende activiteiten rondom de interventie georganiseerd, zoals proeverijen en koken tussen het publiek. Dat vergrootte de beleving van de interventie (Ernst, 2007). Van belang bij de interne communicatie is ook dat (alle) integrale kosten en opbrengsten gecommuniceerd worden. Dat maakt de impact duidelijk voor iedereen (Van den Brok, 2012). 


\subsection{Interventies bij Stichting Vrijwaard en Stichting Omring}

Stichting Vrijwaard

Stichting Vrijwaard heeft een nieuw voedingsconcept ontwikkeld, waarin één van de elementen is dat alle voeding van regionale leveranciers en ook van boeren uit de regio (de Kop van Noord-Holland) komt. Daarnaast wordt meer gebruik gemaakt van verse ingrediënten in plaats van diepvries. Dit wordt gecommuniceerd met de cliënten. De leveranciers komen in het huis-aan-huisblad aan het woord, zij leggen het streekeigen element uit en er wordt meer informatie op de menulijst gegeven. Daarnaast zijn er veranderingen in het aanbieden van de maaltijd en de menukeuze.

\section{Stichting Omring}

Ook bij Stichting Omring wil men meer werken met regionale producten. Daar heeft men drie maanden (van 1 april 2016 - 1 juli 2016) gekozen voor een dag in de week 'regionaal' met producten uit de Kop van Noord Holland. Soms werd ook een typisch streekgerecht gepresenteerd. Er werd gecommuniceerd over 'het streekmenu'. Speciale menukaarten werden op de tafels gezet en op de afdelingen werden de voedingsassistenten over het streekmenu geïnformeerd, zodat zij ook de cliënten konden enthousiasmeren. Eén dag in de week konden cliënten kiezen voor het streekmenu. Het alternatief voor het streekmenu is het menu met andere ingrediënten die niet perse uit de streek komen.

\section{4 'Regionale herkomst niet zo belangrijk'}

Cliënten zeggen regionale herkomst niet zo belangrijk te vinden

Cliënten zeggen zelf dat de regionale herkomst voor hen niet van groot belang is net zo min als informatie over de achtergrond van hun maaltijd. Zie voor een overzicht van alle items rondom de warme maaltijd bijlage 3 .

Cliënten die wel zeggen iets te weten over de herkomst van hun maaltijd zijn tevreden over de mate waarin het menu streekelementen bevat

Cliënten die de vraag over tevredenheid hebben ingevuld zeggen wel tevreden te zijn over het aspect 'regionale herkomst', terwijl de informatie over de achtergrond van hun maaltijd te wensen overlaat.

Geen verschillen tussen man en vrouw en tussen leeftijdsgroepen

Er zijn geen verschillen gevonden tussen de groep mannen en vrouwen en ook niet per leeftijdsgroep, voor zover dat bekeken kon worden in deze (kleine) groepen.

Voldoende informatie over de achtergrond van het eten

De resultaten bij bewoners van Omring (2016) laten zien dat hoe meer men aangeeft dat er voldoende informatie is over de achtergrond van het eten, hoe meer zij vinden dat de maaltijd producten uit Noord-Holland bevatte $(\mathrm{Beta}=.301 ; \mathrm{p}=.066)$. Dit bevestigt de logische stelling dat 'weten waar de producten vandaan komen' belangrijk is om te weten of het streekproducten zijn. Dit hebben we overigens niet gevonden bij cliënten van Vrijwaard en Den Koogh (2015); het lage aantal respondenten is daar debet aan.

\subsection{Weinig kennis over regionale herkomst maaltijd}

Veel cliënten weten weinig over de regionale herkomst van hun maaltijd Bij Stichting Omring (2016) zei 53\% van de ondervraagden 'niet te weten' of ze tevreden zouden moeten zijn over de regionale herkomst. De meerderheid van de ouderen weet dus niet waar de producten vandaan komen. Bij Den Koogh (2015) wist slechts 3 mensen iets te zeggen over de tevredenheid van de regionale herkomst; 35 anderen hebben deze vraag niet beantwoord of zeiden 
het niet te weten. De helft van de cliënten bij Stichting Vrijwaard (2015) (20 mensen) kon de vraag goed beantwoorden; de andere helft wist het niet of heeft deze vraag overgeslagen.

Bij de Stichting Omring kiest één derde van de respondenten (wel eens) voor het streekmenu Van de 89 cliënten kiest 34 altijd (10) of soms (24) voor een streekmenu wanneer dat aangeboden wordt. 10 Respondenten zeggen nooit voor het streekmenu te kiezen en 45 mensen weten niet of ze dat doen. Dit is overigens niet overeenkomstig dat wat de manager Voeding zegt. Daar is het beeld dat $60 \%$ van de mensen het streekmenu kiest wanneer dat wordt aangeboden.

Veel cliënten kennen het streekmenu niet (goed)

Een groot deel van de groep die niet weten of ze voor het streekmenu hebben gekozen kennen het niet, 'hebben er nog nooit van gehoord'. Hierbij wordt opgemerkt dat uit het interview met de voedingsassistenten blijkt dat zij er de bewoners wel over vertellen, maar dat het vergeten wordt.

\section{6 'Smaak en het regionale aspect het belangrijkst'}

Cliënten die het streekmenu kiezen vinden het streekmenu zoals Stichting Omring dat aanbiedt aantrekkelijk, makkelijk om te kiezen en relatief normaal

Tabel B4.19 laat zien dat veel cliënten het streekmenu aantrekkelijk, makkelijk om te kiezen en relatief normaal vinden. Echter ook hier komt naar voren dat een groot aantal mensen 'het niet weet' of 'geen mening heeft'. Vooral veel mensen weten niet of het streekmenu makkelijk is om te kiezen.

Van de mensen die altijd of soms het streekmenu zeggen te kiezen vindt $82 \%$ het makkelijk om het streekmenu te kiezen; $74 \%$ vindt het streekmenu ook aantrekkelijk en $82 \%$ vindt het normaal.

Smaak, 'goed voor de regio' zijn bepalende argumenten voor de keuze voor het streekmenu We hebben vervolgens gekeken naar de cliënten die het streekmenu wel eens hebben gekozen.

Het streekmenu is makkelijk te kiezen vanwege de goede communicatie erover en 'het makkelijk kunnen aankruisen' 30 Cliënten die het makkelijk vonden om het streekmenu te kiezen noemen daarbij vooral het gemak om gewoon het menu aan te kruisen. Ze noemen (ook bij 'makkelijk te kiezen') de smaak als overweging. En deze cliënten vinden het streekmenu goed en duidelijk aangekondigd en gecommuniceerd.

Cliënten die het streekmenu aantrekkelijk vonden noemden vooral de smaak. Het zou een lekker menu zijn. De regionale herkomst werd ook door velen genoemd, evenals 'overig' waar een veelheid aan verschillende elementen naar voren kwam, zoals 'de leuke manier van serveren' en 'herinneringen aan vroeger'. Hier wordt ook wel de link met streekgerechten gelegd. Het streekgerecht 'Ketelkost' wordt - afgemeten aan het aantal keren dat dit in de interviews werd genoemd - erg gewaardeerd.

Ook bij de vraag waarom streekmenu's normaal zijn kwam de smaak weer naar voren. Hier werd bovendien vooral geantwoord 'dat het normaal is dat producten uit de streek komen'. Dat sluit ook bij het antwoord 'dat het zo hoort', 'dat het bekend is'.

Cliënten in een plattelandsomgeving lijken de regionale herkomst meer te verbinden aan 'goed voor de leefbaarheid', 'regionale economie'

Opvallend is het verschil tussen respondenten in de groep van Den Helder en Julianadorp enerzijds en die in Grootebroek en Wognum anderzijds (allemaal zorginstellingen van Omring). In de tweede groep speelde het regionale aspect een grotere rol. Respondenten leken het meer te beleven en meer terug te kunnen voeren op hun eigen (vroegere) leven als boer of op herinneringen aan hun (vroegere) woonomgeving.

Cliënten die niet kiezen voor het streekmenu, 'het niet te weten' of 'er geen mening over hebben' zijn niet negatief over het streekmenu

De mensen die nooit het streekmenu zeggen te kiezen zijn daar niet uitgesproken negatief over. Er is een wat wisselend beeld. $25 \%$ Vindt het makkelijk om het streekmenu te kiezen, maar $50 \%$ 'heeft 
geen idee' of dat eenvoudig is. $40 \%$ zegt het streekmenu wel aantrekkelijk te vinden, maar ook $40 \%$ zegt dat dat niet zo is. $20 \%$ heeft 'geen idee'. $50 \%$ Van de niet-kiezers zegt het wel normaal te vinden om het streekmenu te kiezen en $20 \%$ weet het niet en weer $20 \%$ of 'heeft geen idee'. Er is dus geen negatief beeld van het streekmenu onder de mensen die er niet voor kiezen.

Van de mensen die zegt het niet te weten of ze hebben gekozen voor het streekmenu zegt $71 \%$ (ook) 'niet te weten' of het makkelijk is om daarvoor te kiezen. De meerderheid zegt het streekmenu wel aantrekkelijk te vinden en ook normaal.

\subsection{Meer producten uit de regio vanwege de regionale inbedding en leefbaarheid}

Cliënten zeggen regionale herkomst niet zo belangrijk te vinden

Regionale herkomst is voor cliënten zelf niet zo belangrijk, zo zeggen ook de voedselmanagers van Stichting Vrijwaard en Stichting Omring. 'Uit de streek' leeft weinig onder de bewoners, volgens hen.

Cliënten zeggen leveranciers wél belangrijk te vinden

De voedselmanagers van Stichting Vrijwaard ervaren dat de herkenbaarheid van bepaalde leveranciers wél leeft. Immers 'vis van visboer $\mathrm{X}^{\prime}$ en 'het brood van bakkerij $\mathrm{Y}^{\prime}$ staat voor bepaalde kwaliteit, smaak en beleving. Dat vinden mensen leuk en geeft herkenning en begrip.

Andere overwegingen spelen een hoofdrol bij de keuze voor regionale producten

De voedselmanagers van Stichting Vrijwaard en Stichting Omring noemen andere overwegingen dan de expliciete vraag bij cliënten om regionale producten aan te bieden:

- De bijdrage aan de lokale economie van Noord-Holland, dat vooral door de mantelzorgers wordt gezien en gewaardeerd;

- De verbinding met de omgeving, waarbij een aantal voorbeelden wordt genoemd waarbij sponsoringactiviteiten gemakkelijker worden;

- 'De leveranciers van vandaag zijn de cliënten van morgen';

- Lokaal betekent ook vers;

- Duurzaamheid: Het komt van dichtbij, weinig in transport, 'gezondere kilometers'.

Bovendien kunnen regionale producten aanleiding zijn voor vernieuwing. Er komen nieuwe gerechten op tafel.

\subsection{Meerwarde van biologische herkomst lijkt beperkt}

Cliënten vinden het niet belangrijk en zijn er ook niet zo tevreden over

Cliënten hechten weinig belang aan de biologische productiewijze van hun voedsel (zie tabel B4.22).

Zo zeggen ook de managers die voeding organiseren (Vrijwaard). Ook zij zeggen dat dit aspect niet of nauwelijks speelt. Cliënten zijn er ook weinig tevreden over, waarbij wel de kanttekening past dat het gaat om heel weinig respondenten (zie tabel B4.23).

In bijlage 3 en 4 zijn het belang en de tevredenheid over de andere aspecten van de maaltijd gegeven.

Geen verschillen in geslacht; wel enig verschil tussen leeftijdsgroepen Er zijn geen verschillen gevonden waar het gaat om het geslacht, voor zover dat kon worden achterhaald. Er is enig bewijs dat naarmate inwoners van stichting Vrijwaard ouder worden, hoe belangrijker ze biologisch eten gaan vinden (Beta $=.279 ; \mathrm{p}=.086)$.

Er zijn weinig redenen om meer biologische groenten en fruit aan te bieden

Zoals blijkt hechten cliënten weinig waarde aan de biologische herkomst van hun voedsel. Ook bij mantelzorgers leeft het item niet, volgens de voedselmanagers van Stichting Vrijwaard. Zij noemen 
alleen smaak als mogelijke overweging. Echter, direct daarop volgt dat het voor hen de vraag is of de prijs/kwaliteit verhouding voldoende is. Weegt de (hoge) meerprijs op tegen de extra smaak? Vooralsnog ligt het accent meer op vers dan op biologisch. En vervolgens op de leverantie uit de streek, van bekende lokale leveranciers.

\subsection{Kok, keten en voedingsassistenten essentieel}

Verschillende schakels essentieel

Zoals de andere initiatieven ook ervaren, noemen Stichting Vrijwaard en Stichting Omring ook verschillende schakels als essentieel in het succesvol implementeren van het streekgebonden menu's.

\section{Leveranciers}

Stichting Vrijwaard is volop bezig om meer producten uit de streek te halen. Er komen steeds meer lokale leveranciers - ook in verband met de versheid. Veel belemmeringen ziet Stichting Vrijwaard niet. Het hoeft ook niet duurder te zijn; daarover worden afspraken gemaakt. Stichting Omring ervaart nog wel hogere kosten, die wellicht ook voortkomen uit de keuze om andere, duurdere ingrediënten te gebruiken te maken om het streekmenu 'een speciaal' tintje te geven. Denk hierbij aan Texels lamsvlees als voorbeeld.

\section{Kok en voedingsassistent}

Uiteraard is de kok degene die van de streekproducten smaakvolle maaltijden moet samenstellen. Bij Stichting Omring is de indruk dat het voor de kok makkelijk is om te werken met het streekmenu. 'Als je een goede kok hebt, wordt die enthousiast van streekproducten omdat ze er veel over te vertellen hebben, omdat de producten mooi zijn'. Ook zijn de kok en de voedingsassistente van belang in het overbrengen van het enthousiasme op de cliënten. De kok presenteert de maaltijd aan de mensen aan tafel in het restaurant en de voedingsassistenten brengen de maaltijd bij de mensen op de afdeling in de huiskamer. Voor de voedingsassistenten betekent het streekmenu een extra activiteit/ handeling. Hun houding wisselt ook, zo ervaart Stichting Omring: waar de een enthousiast is en het leuk vindt om iets te vertellen over eten, mooie producten en mooi uit te serveren, is de andere dat minder.

Tot slot, de Raad Van Bestuur en de inkoper. Zij kijken vooral naar de kosten en de concurrentiepositie. 


\section{$7 \quad$ Conclusies en aanbevelingen}

\subsection{Conclusies}

Er zijn kansen voor groenten en fruit bij zorginstellingen

Algemeen

- De uitstraling van groenten en fruit op het bord de eetlust versterkt en een gebrek aan eetlust is een belangrijke belemmering om te eten.

- De aanwezigheid van groenten ertoe leidt dat cliënten de maaltijd lekkerder vinden en vinden dat de maaltijd 'er mooier uitziet'

- Groenten en fruit lekker en gezond gevonden worden door de cliënten zelf

- Cliënten gezond eten ook belangrijk vinden

- Terwijl nog niet genoeg groenten en fruit gegeten wordt en daar dus ruimte 'voor meer' zit.

\section{Aandachtspunten}

- De consumptie van (meer) groenten en fruit beperkt wordt door een algeheel gebrek aan eetlust, kauw- en slikproblemen. Dit vraagt het op maat aanbieden van groenten en fruit (geschild, gesneden).

- De vraag naar meer groenten wordt door een aantal cliënten geformuleerd; hier past een op maat gerichte aanpak bij. Anders is er het risico van voedselverspilling en dit zou het draagvlak voor 'meer groenten aanbieden' sterk afkalven.

Op meerdere eetmomenten

- Cliënten zelf vragen meer fruit op diverse eetmomenten en tussendoor

- Dit sluit aan bij de algemene aanbevelingen om ondervoeding tegen te gaan

- Dit verhoogt het aantal sociale interactiemomenten, belangrijk voor het welbevinden van de cliënten

\section{Aandachtspunten}

- Meerdere eetmomenten vraagt extra organisatie en inzet van (keuken)personeel, terwijl deze vaak beperkt is. Hier zou gedacht kunnen worden aan inzet van vrijwilligers, mantelzorgers of bezoekers. Ook kan dit aanleiding zijn om met de leveranciers om tafel te gaan en te verkennen welke mogelijkheden voor meer op maat aanbieden er zijn.

- Groenten op andere momenten dan bij de warme maaltijd past niet goed in de gewoonten van ouderen. Zij zijn vooral gewend om groenten te eten als onderdeel van de warme maaltijd.

Meer groenten bij de warme maaltijd

- Een deel van de cliënten vraagt om meer groenten bij de warme maaltijd

- Dit sluit aan bij hun gewoonten, waarbij Hollandse kost vaak genoemd wordt. Hollandse kost wordt ook als gezond beschouwd.

\section{Aandachtspunten}

- Niet iedereen vraagt meer groenten; het gaat hier om een individueel passend aanbod

- Meer groenten in de vorm van salade of rauwkost kan de consumptie van de hoofdgroenten doen afnemen.

Uit de regio

- Voor de zorginstellingen zelf bieden regionale producten de mogelijkheid om verbinding te zoeken met (potentiele) klanten en de regionale inbedding te vergroten

- Om de maaltijd lekkerder en verser te kunnen presenteren, volgens cliënten

- Om het bewustzijn van cliënten te vergroten over de voordelen van voeding uit de regio voor de regionale economie en leefbaarheid.

- Om er verhalen over te kunnen vertellen 


\section{Aandachtspunten}

- De organisatie van regionale ketens vraagt tijd, inzet en geduld.

- Er kan ook sprake zijn van meerkosten; zeker wanneer alleen gekeken wordt naar de kosten van de voeding. Wanneer ook andere effecten worden meegenomen wegen de meerkosten op tegen de meeropbrengsten, zo melden verschillende initiatieven

- Om het bewustzijn bij cliënten te verhogen is communicatie - op verschillende manieren - nodig. Bovendien moet dit herhaaldelijk en veelvuldig gebeuren.

Heel weinig kansen voor groenten en fruit van biologische herkomst

- Deze producten hebben een hoger gehalte aan voedingsstoffen vergeleken met gangbare producten

Aandachtspunten

- De hogere prijs vormt een belemmering

- Cliënten vragen nauwelijks om biologische producten

\subsection{Aanbevelingen}

\section{Voor zorginstellingen}

- Bied meer groenten en fruit aan cliënten aan

- Aansluitend bij de individuele behoeften om voedselverspilling te voorkomen

- Zorg daarbij voor meerdere eetmomenten - met name voor fruit

- En focus het groente-aanbod op de warme maaltijd

- En kijk ook naar momenten buiten de warme maaltijd, maar bedenk dat er dan gewoonten van cliënten doorbroken moeten worden

- Ga met leveranciers van groenten en fruit om tafel om de mogelijkheden te verkennen om producten op maat aangeboden te krijgen

- Versterk de regionale component

- Wees bewust van het feit dat de organisatie van regionale ketens veel tijd en inzet vraagt

- Versterk de verbinding met de cliënten door (leveranciers en producenten te laten) vertellen over regionale producten en voeding

Voor leveranciers van groenten en fruit

- Denk mee om te komen tot concepten om meer groenten en fruit aan te bieden zodat zorginstellingen gemakkelijk meer groenten en fruit kunnen aanbieden op een manier die aantrekkelijk is voor hen en hun cliënten en aansluitend bij hun bedrijfsvoering

- Denk mee om te komen tot concepten passend bij specifieke kenmerken van hun cliënten: gebrek aan eetlust, kauw- en slikproblemen

- Bouw samen met zorginstellingen aan nieuwe productconcepten voor diverse eetmomenten

- Bouw aan regionale concepten waarin verschillende producten in de juiste hoeveelheid, de juiste kwaliteit en de juiste kwaliteit/prijs verhouden wordt aangeboden

- Ontwikkel communicatiemateriaal samen met zorginstellingen om cliënten en hun (mantel)omgeving te informeren over regionale producten

- Ontwikkel activiteiten voor cliënten en hun (mantel)omgeving rondom regionale producten

Voor onderzoek

- Ontwikkel meer inzicht in de effectiviteit van interventies om meer groenten en fruit aan te bieden aan cliënten in zorginstellingen. Neem bij deze interventies de consumptie van groenten en fruit, de gezondheid van de cliënten en het draagvlak onder stakeholders bij de zorginstellingen in ogenschouw. Is de interventie ook voor hen gemakkelijk, aantrekkelijk en passend bij hun bedrijfsvoering? 


\section{Literatuur en websites}

Abbott, R.A. et al. (2013) Effectiveness of mealtime interventions on nutritional outcomes for the elderly living in residential care: A systematic review and meta-analysis In: Ageing Research Reviews 12 (2013) 967-981

Actiz - organisatie van zorgondernemers (2015) Verbinding geeft kracht - Achtergronden van de Benchmark in de zorg 2015

Ajzen, I. (1991) The theory of planned behavior. Organizational Behavior and Human Decision Processes, 50, pp. 179-211

Boers, I. et al. (2012) Evaluatie van een voedingsconcept gebaseerd op streekgebonden, biologische voeding en aandacht voor ambiance in een woonzorgcentrum voor ouderen, Louis Bolk Instituut, LBI-rapport 2013-010 VG

Borgdorff, A. (2011) Kansen voor groenten en fruit in de zorg en sport, Productschap Tuinbouw, Markt\&Innovatie, PT 2011-16

Brok, den P., M. Gorselink (2010) De genietende groene tafel - een pilot onderzoek naar wat goed eten en drinken binnen de zorgsector kan opleveren. Wageningen UR.

Brok, den P. (2012) Bio- en streekproduct positiever op de kaart in: Food Hospitality (2012) pp19-21

Carrier, N. et al. (2009) 'Dining experience, foodservices and staffing are associated with quality of life in elderly nursing home residents' in The Journal of Nutrition, Health \& Aging Volume 13, Number 6, 2009

CBS (2012) CBS Bevolkingsprognose voor 2013-2060, Den Haag

CBS (2015) Nederland eet onvoldoende groente, fruit en vis - CBS, Statline, Leefstijl en (preventief) gezondheidsonderzoek: persoonskenmerken - http://statline.cbs.nl/statweg/publication -

Compendium voor de Leefomgeving, www.clo.nl/indicatoren/nl0001-bevolkingsomvang-enhuishoudens

Curle, L. and H. Keller, (2009) 'Social Interactions Among Mealtime Tablemates in Assisted Living'

De Castro, J.M., and E.M. Brewer (1992) The amount eaten in meals by humans is a power function of the number of people present Physiology\&Behaviour, 51: 121-125, 1992

De Castro (1994) 'Family and Friends Produce Greater Social Facilitation of Food Intake Than Other Companions' in : Psychology\&Behavior, Vol. 56, pp. 445-455, 1994

De Castro, J.M. (1995) 'Social facilitation of Food Intake in Humans' in Appetite (1995) 24, pp. 260

Diverzio, Rapportage Voedselafvalmeting Vrijwaard locaties Ten Anker en De Golfstroom, 19 februari 2015

Edwards and Hartwell (2004) A comparison of energy intake between eating positions in a NHS hospital - a pilot study In: Appetite 43 (2004) 323-325 
Ernst, M. (2007) Biologische warme maaltijden in de Zeeuwse zorg - Evaluatie pilot 2006-2007, Zeeuwse Milieufederatie

Ervin, R.B., B.A. Dye. The effect of functional dentition on Healthy Eating Index scores and nutrient intakes in a nationally representative sample of older adults, J Public Health Dent 2009; 69: 207-16)

Fjellstrőm, C., B. Sidenvall and M. Nydahl (2001) 'Food Intake and the Elderly - Social Aspects' in Food, People and Society - a European Perspective of Consumers' Food Choices (Frewer, L. et al., ed.)

Halfens, R.J.G. et al., (2010) Landelijke Prevalentiemeting Zorgproblemen 2010, Universitaire Pers Maastricht

Halfens, R.J.G, et al. (2016) Prevalentiemeting Zorgproblemen - Rapportage resultaten 2015 - CAPHRI School for Public Health and Primary Care - Department of Health Services Research - Focusing on Chronic Care and Ageing

Herman, C.P. and J. Polivy (2005) 'Normative influences on food intake' in Physiology\&Behavior $86(2005) 762-772$

Hermans, R.C.J. (2015) Aan tafel! Hoe de aanwezigheid van anderen ons eetgedrag beinvloedt tijdschriftissue in: The Inquisitive Mind 2015, nummer 3

http://nl.in-mind.org/article/aan-tafel-hoe-de-aanwezigheid-van-anderen-ons -eetgedrag beïnvloedt

Hermens, R. (2012) Duurzame streekproducten in de zorg

Informatorium Voeding en Dietetiek, (2016) Voeding van de oudere mens, pp. 139-158

Jobse-van Putten, J. (1995) Eenvoudig maar voedszaam - Cultuurgeschiedenis van de dagelijkse maaltijd in Nederland, SUN Memoria

Jong, de M. (2012) Impuls aan regionale economie - In: Food Hospitality (2012) juni - pp. 10-12

Kayser-Jones, J. and E. Schell (1997) The effect of staffing on the quality of care at mealtime. Nursing Outlook 45(2)64-72

King, S.C. et al. (2004) 'The effect of meal situation, social interaction, physical environment and choice on food acceptability' in Food Quality and Preference 15 (2004) 645-653

Kok, L. et al. (2014) Ondervoeding onderschat - de kosten van ondervoeding en het rendement van medische voeding, SEO Economisch Onderzoek, Amsterdam

Lumeng, J.C. en K.H. Hillman (2007) Eating in larger groups increases food consumption In Archives of Disease in Childhood; 92, 384-387

Meeusen, M.J.G. (2010) Sociale context en eetgedrag. LEI ????

Meeuwsen, F. (2015) Versproducten in Zorg, foodsteps -http://fsfacts.nl/vers-in-zorg

Meij, van der B. en H. Kruizinga (2016) Voedingsconcepten in de Nederlandse Ziekenhuizen samenvatting van de bevindingen - Een inventarisatie door de Stuurgroep Ondervoeding, in opdracht van het ministerie van VWS -

Ministerie van Landbouw, Natuur en Voedselkwaliteit (12 maart 2010) LNV Consumentenplatform 'Gezond leven, een leven gezond' Over ouderen en gezonde voeding 
Ministerie van Volksgezondheid, Welzijn en Sport \& Ministerie van Landbouw, Natuur en Voedselkwaliteit (2008) Gezonde Voeding, van begin tot eind, Nota Voeding en Gezondheid, Den Haag

Nijs, K.A.N.D., et al. (2006) Effect of family style mealtimes on quality of life, physical performance and body weight of nursing home residents: cluster randomised controlled trial in BMJm doi: 10.1136

Ocke, M. et al. (2013) Diet of community-dwelling older adults : Dutch National Food Consumption Survey Older adults 2010-2012, Rijksinstituut voor Volksgezondheid en Milieu

Paquet, C. et al. (2008) 'More than Just nog Being Alone: The Number, Nature and Complementarity of Meal-Time Social Interactions Influence Food Intake in Hospitalized Elderly Patiens' in 'the Gerontologist' Volume 48, No. 5, 2008 pp. 603-611

Raghoebar, S. (2011) Gebruik van duurzame producten nauwelijks duurder. In: Food Hospitality (oktober 2011) pp. 14

Raynaud-Simon, A. and C. Aussel (2012) Fruit and vegetable intake in older hospitalized patients. In Current Opinion Clinical Nutrition Metab Care. 2012 Jan;15(1):42-6.

Redd, M. and J.M. de Castro (1992) 'Social Facilitation of Eating: Effects of Social Instruction on Food Intake' in Physiology \& Behavior, Vol. 52, pp. 749-754, 1992

Reinders, M.J. et al. (2012) Het stimuleren van gezonde voedselkeuzes : onderzoek gericht op schoolkantines en zorginstellingen, LEI Wageningen UR

Rijksinstituut voor Volksgezondheid en Milieu, Nationaal Kompas Volksgezondheid: www.nationaalkompas. $\mathrm{nl}>$ Bevolking > Vergrijzing

Rijksinstituut voor Volksgezondheid en Milieu, Nationaal Kompas Volksgezondheid: www. nationaalkompas. nl/zorg/huidig-zorgaanbod

Schoorel, E. (2011) Ter Reede zet door met biologisch In: Food Hosipitality (2011) september pp. $10-13$

Staveren, van W.A. en C.P.G.M. de Groot, Nationaal Kompas Volksgezondheid 'Voeding - Lage energie-inname bij ouderen'

Tsakos, G., K. Herrick, A. Sheiham, R.G. Watt (2010) Edentulism and fruit and vegetable intake in low income adults, J Dent Res 2010: 89: 462-7

Vilans, (2012) Kennisbundel Eten en drinken - Voor docenten Zorg en Welzijn

Vingerhoeds M. (2014) Op weg naar een hogere groente-en fruitconsumptie: barrières en succesfactoren: Eerste inventarisatie en verkenning van kennis en kansrijke interventies rondom het verhogen van de groente-en fruitconsumptie, FBR - Wageningen UR, rapport 1431

Vijver, L. van de (2014) Biologische Groente en fruitinterventies - achtergrond ouderen, Louis Bolk Instituut

Vijver, L. van de, et al. (2016) Verhogen van groente- en fruitconsumptie - (Biologische) groente en fruit interventie bij kinderen in kinderdagverblijven, Louis Bolk Instituut

Visser, M. en C. Dijkstra (2011a) Eetgedrag van ouderen, EMGO+Instituut, VU Medisch Centrum Amsterdam 
Visser, M. en C. Dijkstra (2011b) Naar verklaringen voor het eetgedrag van ouderen, EMGO+Instituut, VU Medisch Centrum Amsterdam

Voedingscentrum (2016), Factsheet Ouderen en voeding

Wansink, B. (2015). Change their choice! Changing behavior using the CAN approach and activism research. Psychology \& Marketing, 32(5), 486-500.

Wansink, B., \& Van Ittersum, K. (2012). Fast food restaurant lighting and music can reduce calorie intake and increase satisfaction. Psychological Reports, 111(1), 228-232.

Whear R. et al (2014) Effectiveness of mealtime Interventions on Behavior Symptoms of People With Dementia Living in Care Homes: A Systematic Review In: JAMDA 15 (2-14) 185-19

Woittiez, I. et al. (2009) Vergrijzing, verpleging en verzorging - Ramingen, profielen en scenario's Sociaal en Cultureel Planbureau, Den Haag

http://www.clo.nl/indicatoren/nl0001-bevolkingsomvang-en-huishoudens: 


\section{Bijlage 1 Stichting Vrijwaard en Stichting Omring}

\section{Stichting Vrijwaard}

Stichting Vrijwaard verzorgt dagelijks maaltijden voor drie groepen cliënten:

- De cliënten in drie woon- en zorgcentra (Ten Anker, De Golfstroom en De Westhoek wonen en eten - in hun eigen appartement of

- in het restaurant van het woon- en zorgcentrum

- De cliënten die wonen in de omgeving en naar het restaurant komen om daar te eten

- De cliënten die nog thuis wonen en gebruik maken van maaltijden die de Stichting Vrijwaard aanbiedt.

\section{Stichting Omring}

\begin{tabular}{lllll} 
Plaats & Vestiging & $\begin{array}{l}\text { Wonen met zorg } \\
\text { dichtbij }\end{array}$ & $\begin{array}{l}\text { Behandeling en } \\
\text { verpleging }\end{array}$ & $\begin{array}{l}\text { Kleinschalig wonen } \\
\text { voor mensen met } \\
\text { dementie }\end{array}$ \\
Den Helder & Den Koogh & $\mathrm{X}$ & $\mathrm{X}$ & $\mathrm{X}$ \\
\hline Julianadorp & Buitenveld & $\mathrm{X}$ & $\mathrm{X}$ & $\mathrm{X}$ \\
\hline Wognum & Sweelinckhof & $\mathrm{X}$ & & $\mathrm{X}$ \\
\hline Grootebroek & Rigtershof & $\mathrm{X}$ & & $\mathrm{X}$ \\
\hline
\end{tabular}




\section{Bijlage 2 Toelichting op de activiteiten}

\section{Enquêtes onder cliënten}

Enquête 1: Enquête onder de cliënten van Stichting Vrijwaard in augustus 2015 In augustus 2015 is onder 41 cliënten van de Stichting Vrijwaard een enquête gehouden. Zij woonden intern. Zij zijn met de hulp van studenten geënquêteerd.

Tabel B2.1 Het geslacht en de leeftijd van de respondenten van Stichting Vrijwaard in augustus 2015

\begin{tabular}{lllll} 
& Aantal mannen & Aantal vrouwen & Totaal & Leeftijd (jaar) \\
De groep 'Vrijwaard Intern' & $13(32,5 \%)$ & $27(67,5 \%)$ & $40(100 \%)$ & $83(56-95)$ \\
\hline
\end{tabular}

Doel van de enquête was antwoord te vinden op de vraag 'Hoe belangrijk vinden cliënten de verschillende elementen van het voedingsconcept?' en 'Hoe tevreden zijn ze daarover?'. Daarbij kwamen de verschillende factoren aan de orde die van belang zijn bij de waardering van voedsel, zoals smaak, gemak, gezondheid. Daarnaast is expliciet gevraagd naar elementen die veranderd zijn in het nieuwe concept, zoals herkomst, ambiance, variatie.

Enquête 2: Enquête onder de cliënten van Stichting Omring in augustus 2015

In augustus 2015 is onder 30 cliënten van de Stichting Omring dezelfde enquête uitgezet als de bovengenoemde, eerste enquête. Ook hier hebben studenten geholpen om de vragenlijsten in te vullen. Het ging om mensen (25) die intern wonen.

De groep respondenten betrof iets meer mannen dan vrouwen: 16 mannen $(53,3 \%)$ en 14 vrouwen $(46,7 \%)$. De gemiddelde leeftijd was 75 jaar, uiteenlopend van 46 tot 94 jaar.

Tabel B2.2 Het geslacht en de leeftijd van de respondenten van Stichting Omring in augustus 2015

\begin{tabular}{lllll}
\hline Den Koogh - aug 2015 & $16(53,3 \%)$ & $14(46,7 \%)$ & $30(100 \%)$ & $75(46-94)$ \\
\hline
\end{tabular}

Enquête 3: Enquête onder de cliënten van Stichting Omring in juni 2016

In juni 2016 is een derde enquête uitgezet. Studenten hebben 92 cliënten geholpen met het invullen ervan.

In deze enquête is de nadruk gelegd op (i) de wensen ten aanzien van (i) groenten en fruit en (ii) de ervaringen met de interventie die Omring heeft uitgevoerd.

Tabel B2.3 Het geslacht en de leeftijd van de respondenten van Stichting Omring in augustus 2015

\begin{tabular}{lllll} 
& Aantal mannen & Aantal vrouwen Totaal & Leeftijd (jaar) \\
Omring - juni 2016 & $29(31,5 \%)$ & $63(68,5 \%)$ & $92(100 \%)$ & $81(47-101)$ \\
\hline
\end{tabular}




\section{Een interview met het management rondom voeding van Stichting Vrijwaard en Stichting}

Omring

Het doel van het interview met het management rondom voeding van Stichting Vrijwaard en Stichting Omring was te komen tot meer inzicht in de mogelijkheden en belemmeringen om meer (biologische) groenten en fruit (uit de streek) aan de cliënten van de betreffende zorginstelling (Stichting Vrijwaard en Stichting Omring) aan te bieden.

In het interview werd de volgende lijn aangehouden;

- Wat zouden redenen en overwegingen voor de betreffende zorginstelling kunnen zijn om meer groenten en fruit aan te bieden? Waarom zou zij over die optie willen nadenken?

- Welke mogelijkheden ziet de betreffende zorginstelling om meer groenten en fruit aan te bieden?

- Welke belemmeringen zijn er?

- Hoe zouden deze belemmeringen weggenomen/ verminderd kunnen worden? Wat is daar voor nodig - door wie?

De aanpak is dezelfde voor beide instellingen, Stichting Vrijwaard en Stichting Omring. Het interview met het management van de Stichting Vrijwaard is 16 februari 2016 gehouden; met het management van de Stichting Omring is 30 juni 2016 gesproken.

Bij de Stichting Vrijwaard is gesproken met:

- Grietje de Vries: Project- en preventiemanager, vooral in facilitaire projecten (ARBO, huisvesting)

- Ruud Jekkers: beleid, innovatie, nieuwbouw, service (receptie, voeding, catering). MT-lid (waarvan

2 zorg, 1 HRM, 1 F\&C en 1 PR\&Marketing) onder de Raad van Bestuur

- Ivar Borst: coördinator voeding en gastvrijheidscoach

Bij de Stichting Omring is 30 juni 2016 gesproken met Maarten van Dijk, manager Voeding.

\section{Een focusgroep met medewerkers van de Voedingsdienst van Stichting Vrijwaard}

Het doel van de focusgroep met 8 mensen uit de Voedingsdienst die de warme maaltijd bij de mensen rondbrengen, is te verkennen welke mogelijkheden er zijn om 'consumptie van groenten en fruit te verhogen'.

Aan de deelnemers aan de focusgroep is gevraagd om door de ogen van de cliënt de vragen te beantwoorden. Daarbij ging het om de vraag of er ruimte is om meer groenten en fruit aan te bieden en ook welke aanknopingspunten er zijn: andere momenten, andere producten, andere bereidingsvormen, andere manier van aanbieden: op het bord. Tijdens de focusgroep stonden groente centraal en is op gezette momenten een uitstapje gemaakt naar fruit.

Bij de focusgroep Stichting Vrijwaard die 16 februari 2016 gehouden werd, waren 6 deelnemers aanwezig. Daarvan werkten 3 deelnemers als keukenhulp; 1 deelnemer bracht de maaltijden rond naar de mensen die nog zelfstandig wonen, 1 deelnemer werkte in het restaurant en de chef-keuken was erbij. Slechts enkele deelnemers hadden dus direct contact met de cliënten : de chauffeur en de bedienster in het restaurant. De indruk is dat het personeel uit de keuken wel enig zicht had op wat er speelde, maar minder direct geïnformeerd werd door de cliënten. Het personeel dat direct contact heeft met de mensen die op hun kamer eten was niet vertegenwoordigd. 


\section{Bijlage 3 Belang elementen warme maaltijd}

Uit tabel B3.1 blijkt dat de geënquêteerde cliënten de volgende factoren (heel) belangrijk vinden:

- voldoende keuze

- veel vlees of vis

- veel groenten

- verse groenten

- vers fruit

- informatie over de achtergrond

- informatie over het menu

- uiterlijk van de maaltijd

- goede temperatuur goede smaak en

- gastvrijheid

Niet of nauwelijks van belang vinden geënquêteerde cliënten de herkomst: biologisch dan wel regionaal.

Dat veel fruit niet (heel) belangrijk gevonden wordt kan worden verklaard uit het feit dat

- de focus van de enquête lag op de warme maaltijd en slechts 5-15\% van de cliënten eet dan fruit; fruit wordt vooral tussendoor gegeten (40-55\%),

- cliënten vaak zelf zorgen voor hun fruit,

- daarbij geholpen door hun mantelzorgers die (op bezoek) fruit meenemen.

Tabel B3.1 Belang dat cliënten van Stichting Vrijwaard en Stichting Omring (vestiging Den Koogh) hechten aan verschillende elementen van de maaltijd, $n=109$

\begin{tabular}{|c|c|c|}
\hline & Vrijwaard intern & Den Koogh \\
\hline $\begin{array}{l}\text { Van groot belang } \\
(3.5-5)\end{array}$ & $\begin{array}{l}\text { - Voldoende keuze } \\
\text { - Veel vlees / vis } \\
\text { - Veel groenten } \\
\text { - Verse groenten } \\
\text { - Vers fruit } \\
\text { - Informatie achtergrond } \\
\text { - Uiterlijk } \\
\text { - Goede temperatuur } \\
\text { - Goede smaak } \\
\text { - Gastvrijheid }\end{array}$ & $\begin{array}{l}\text { - Veel vlees / vis } \\
\text { - Gastvrijheid } \\
\text { - Voldoende keuze } \\
\text { - Veel groenten } \\
\text { - Informatie achtergrond } \\
\text { - Verse groenten } \\
\text { - Uiterlijk } \\
\text { - Goede temperatuur } \\
\text { - Goede smaak }\end{array}$ \\
\hline $\begin{array}{l}\text { Van midden groot/klein belang } \\
(2.5-3.5)\end{array}$ & $\begin{array}{l}\text { - Veel fruit } \\
\text { - Biologische herkomst }\end{array}$ & - Teveel \\
\hline $\begin{array}{l}\text { Van klein belang } \\
(1-2.5)\end{array}$ & $\begin{array}{l}\text { - Te veel } \\
\text { - Veel uit Noord-Holland }\end{array}$ & $\begin{array}{l}\text { - Veel uit NoordHolland } \\
\text { - Biologische herkomst }\end{array}$ \\
\hline
\end{tabular}




\section{Bijlage 4 Tabellen}

Tabel B4.1 Aanpak van het onderzoek

\begin{tabular}{|c|c|c|c|}
\hline & \multirow[b]{2}{*}{ Focus } & \multicolumn{2}{|c|}{ Invalshoek } \\
\hline & & Cliënten & Instelling \\
\hline \multicolumn{4}{|l|}{ Enquêtes bij cliënten zelf } \\
\hline $\begin{array}{l}\text { Stichting Vrijwaard augustus } \\
2015\end{array}$ & $\begin{array}{l}\text { Tevredenheid en belang van verschillende factoren van de } \\
\text { warme maaltijd op één moment }\end{array}$ & $x$ & \\
\hline $\begin{array}{l}\text { - Stichting Omring - } \\
\text { augustus } 2015\end{array}$ & $\begin{array}{l}\text { Tevredenheid en belang van verschillende factoren van de } \\
\text { warme maaltijd voor de interventie bij de Stichting Omring }\end{array}$ & $x$ & \\
\hline $\begin{array}{l}\text { - Stichting Omring - juni } \\
2016\end{array}$ & $\begin{array}{l}\text { Tevredenheid van verschillende factoren van de warme } \\
\text { maaltijd na de interventie bij de Stichting Omring }\end{array}$ & $x$ & \\
\hline \multicolumn{4}{|l|}{$\begin{array}{l}\text { Interview met management } \\
\text { rondom voeding }\end{array}$} \\
\hline - Stichting Vrijwaard & $\begin{array}{l}\text { Mogelijkheden, belemmeringen, oplossingen voor (i) meer } \\
\text { groenten en fruit, (ii) van biologische herkomst en (iii) uit } \\
\text { de regio }\end{array}$ & $x$ & $x$ \\
\hline - Stichting Omring & $\begin{array}{l}\text { Mogelijkheden, belemmeringen, oplossingen voor (i) meer } \\
\text { groenten en fruit, (ii) van biologische herkomst en (iii) uit } \\
\text { de regio }\end{array}$ & $x$ & $x$ \\
\hline \multicolumn{4}{|l|}{$\begin{array}{l}\text { Interviews en Focusgroep bij } \\
\text { Voedingsdienst }\end{array}$} \\
\hline - Stichting Vrijwaard & $\begin{array}{l}\text { Mogelijkheden, belemmeringen, oplossingen voor (i) meer } \\
\text { groenten en fruit, (ii) van biologische herkomst en (iii) uit } \\
\text { de regio }\end{array}$ & $x$ & $x$ \\
\hline - Stichting Omring & $\begin{array}{l}\text { Tevredenheid en belang van verschillende factoren van de } \\
\text { warme maaltijd na de interventie bij de Stichting Omring }\end{array}$ & & $x$ \\
\hline
\end{tabular}

Zie voor een verdere toelichting bijlage 2 .

Tabel B4.2 Aandeel van de ouderen die in 2010-2012 niet voldoende fruit en groenten eten conform de Richtlijn voor Goede Voeding, in procenten

\begin{tabular}{lll} 
Man & Onvoldoende fruit & Onvoldoende groenten \\
\hline Vrouw & $74 \%$ & $46 \%$ \\
\hline
\end{tabular}

Bron: Ocke (2013).

Tabel B4.3 Aandeel van de ouderen die in 2014 voldoende fruit en groenten eten - conform de Richtlijn voor Goede Voeding, in procenten

\begin{tabular}{lll} 
Leeftijd (jaar) & Voldoende fruit & Voldoende groenten \\
$65-75$ & $40 \%$ & $36 \%$ \\
\hline Ouder dan 75 & $46 \%$ & $43 \%$ \\
\hline
\end{tabular}

Bron: CBS (2015). 
Tabel B4.4 Aandeel cliënten dat minder gegeten heeft en de oorzaken daarvan in 2015

Aantal deelnemers

\section{$N=3.061$}

Aandeel cliënten dat minder gegeten heeft

- Gedurende 1-3 dagen $1,1 \%$

- Gedurende 4-7 dagen $\quad 0,5 \%$

- Langer dan 7 dagen $\quad 3,8 \%$

Oorzaken $\quad \mathrm{N}=165$

- Verminderde eetlust $\quad 54,4 \%$

- Misselijkheid $12,1 \%$

- Problemen met kauwen $7,9 \%$

- Problemen met slikken $\quad 9,7 \%$

- Actuele ziekte $\quad 43,0 \%$

- Pijn $8,5 \%$

- Nuchter zijn $\quad 0,6 \%$

- Anders 20,0\%

Bron: Halfens (2016).

Tabel B4.5 Kenmerken van bewoners in verpleeg- en verzorgingstehuizen in 2005

\begin{tabular}{|c|c|c|}
\hline & Verpleegtehuis & Verzorgingstehuis \\
\hline Leeftijd & 85 & 80 \\
\hline Vrouw (\%) & 75 & 68 \\
\hline Weduwstaat (\%) & 69 & 52 \\
\hline Alleenstaand (\%) & 19 & 47 \\
\hline Opleiding $^{3}$ & 1.6 & 1.9 \\
\hline Huishoudelijke inkomen ${ }^{4}$ & 2.7 & 2.7 \\
\hline Beperkingen $^{5}$ & 3.7 & 4.0 \\
\hline Chronische aandoening (\%) & 90 & 97 \\
\hline
\end{tabular}

Bron: Woittiez (2009).

\footnotetext{
3 Score 1 is laag; score 4 is hoog

4 Score 1 is laag; score 9 is hoog

${ }^{5}$ Score 1 is geen; score 4 is ernstig
} 
Tabel B4.6 De meest ideale en de minst ideale situatie per kenmerk van voedingsconcept in de Nederlandse ziekenhuizen

\begin{tabular}{|c|c|c|c|c|}
\hline Kenmerk & Meest optimale situatie & $\%$ & Minst optimale situatie & $\%$ \\
\hline \multicolumn{5}{|l|}{ Voedingsconcept } \\
\hline $\begin{array}{l}\text { - Mogelijkheden voor maaltijden en } \\
\text { tussendoortjes op zorgafdeling }\end{array}$ & $\begin{array}{l}\text { Onbeperkte mogelijkheden voor } \\
\text { koude en warme maaltijden en } \\
\text { tussendoortjes }\end{array}$ & $*$ & $\begin{array}{l}\text { Minimale mogelijkheden } \\
\text { voor tussendoortjes, } \\
\text { hoofdmaaltijden op vaste } \\
\text { tijdstippen vanuit keuken }\end{array}$ & $*$ \\
\hline - Voedingswaarde & $\begin{array}{l}\text { Richtlijnen voedingswaarde voor } \\
\text { maaltijden of tussendoortjes } \\
\text { vastgesteld, voedingswaarde } \\
\text { bekend }\end{array}$ & $90 \%$ & $\begin{array}{l}\text { Geen richtlijnen } \\
\text { voedingswaarde voor } \\
\text { maaltijden of } \\
\text { tussendoortjes vastgesteld, } \\
\text { voedingswaarde onbekend }\end{array}$ & $10 \%$ \\
\hline - Flexibel koken & $\begin{array}{l}\text { Flexibel: onbeperkt aantal } \\
\text { eetmomenten }\end{array}$ & $9 \%$ & $\begin{array}{l}\text { Vaste eetmomenten, geen } \\
\text { afwijkingen mogelijk }\end{array}$ & $89 \%$ \\
\hline - Eigentijds & Modern - na 2010 ingevoerd & $46 \%$ & $\begin{array}{l}\text { Traditioneel - voor } 2010 \\
\text { ingevoerd }\end{array}$ & $43 \%$ \\
\hline \multicolumn{5}{|l|}{ Bestelprocedure } \\
\hline - Presentatie assortiment & Menukaart & $54 \%$ & Geen menukaart & $45 \%$ \\
\hline - Bestelprocedure & $\begin{array}{l}\text { Flexibel, kort van te voren, zelf } \\
\text { kiezen hoe te bestellen }\end{array}$ & $19 \%$ & $\begin{array}{l}\text { Minstens } 24 \text { uur van te } \\
\text { voeren, via papieren lijst }\end{array}$ & $4 \%$ \\
\hline \multirow[t]{2}{*}{ - Tijd tussen bestellen en serveren } & $<60$ minuten & $35 \%$ & $>12$ uur & $*$ \\
\hline & $>60$ minuten & $64 \%$ & & \\
\hline \multicolumn{5}{|l|}{ Assortiment } \\
\hline $\begin{array}{l}\text { - Aangepaste voeding voor } \\
\text { doelgroepen }\end{array}$ & Aangepaste voeding & $49 \%$ & Alle groepen hetzelfde & $41 \%$ \\
\hline - Beleg & $\begin{array}{l}\text { Kan in onbeperkte hoeveelheden } \\
\text { besteld worden }\end{array}$ & $55 \%$ & $\begin{array}{l}\text { Kan in beperkte } \\
\text { hoeveelheden besteld } \\
\text { worden }\end{array}$ & $8 \%$ \\
\hline - Tussendoortjes en maaltijden & $\begin{array}{l}\text { Kunnen beiden in onbeperkte } \\
\text { hoeveelheden besteld worden }\end{array}$ & $16 \%$ & $\begin{array}{l}\text { Kunnen in beperkte } \\
\text { hoeveelheden besteld } \\
\text { worden }\end{array}$ & $43 \%$ \\
\hline - Bekendheid met assortiment & Bij 3 van de 4 partijen $^{6}$ bekend & $34 \%$ & $\begin{array}{l}\text { Bij minder dan } 3 \text { van de } 4 \\
\text { partijen }{ }^{7} \text { bekend }\end{array}$ & $66 \%$ \\
\hline \multicolumn{5}{|l|}{ Ambiance } \\
\hline - Presentatie warme maaltijd & $\begin{array}{l}\text { Niet afgedekt, ter plekke } \\
\text { opgeschept }\end{array}$ & $27 \%$ & $\begin{array}{l}\text { Van te voren op dienbladen } \\
\text { op deksel getransporteerd } \\
\text { naar afdeling en met deksel } \\
\text { uitgeserveerd }\end{array}$ & $67 \%$ \\
\hline - Locatie om te eten & In dagverblijf of restaurant & $46 \%$ & In eigen kamer in bed & $49 \%$ \\
\hline - Eten met bezoek & $\begin{array}{l}\text { Bezoek kan te alle tijden (gratis) } \\
\text { mee-eten }\end{array}$ & $46 \%$ & Bezoek kan niet mee eten & $47 \%$ \\
\hline - Hulp bij eten & $\begin{array}{l}\text { Altijd aanwezig bij eten, indien } \\
\text { nodig verpleegkundige hulp }\end{array}$ & $74 \%$ & $\begin{array}{l}\text { Er is beperkte tot geen } \\
\text { hulp aanwezig }\end{array}$ & $14 \%$ \\
\hline
\end{tabular}

*: dit item is niet nagevraagd in enquête

Bron: Van der Meij en Kruizinga (2016).

6 Diëtist, voedingsassistent, verpleegkundige, patiënt.

7 Diëtist, voedingsassistent, verpleegkundige, patiënt. 
Tabel B4.7 Belang dat cliënten van Stichting Vrijwaard en Stichting Omring hechten aan hoeveelheid en versheid van groenten en fruit bij de warme maaltijd in 2015; 1 = helemaal mee oneens; 3 = neutraal; 5 = helemaal mee eens

\begin{tabular}{lcc} 
Voor mij is het belangrijk aan de warme maaltijd dat & Vrijwaard $(\mathbf{N}=39)$ & Den Koogh $(\mathbf{N}=37)$ \\
deze: & 4,8 & 4,7 \\
Veel groenten bevat & 2,9 & 3,7 \\
\hline Veel fruit bevat (het dessert) & 4,8 & 4,7 \\
\hline Verse groenten bevat & 4,5 & 4,4 \\
\hline Vers fruit bevat (het dessert)
\end{tabular}

Tabel B4.8 Tevredenheid van de cliënten van Stichting Vrijwaard en Stichting Omring over hoeveelheid en versheid van groenten en fruit in de warme maaltijd in 2015 (Stichting Vrijwaard, Den Koogh) en 2016 (Stichting Omring); 1 = helemaal niet tevreden; 5 = heel tevreden

\begin{tabular}{llll}
$\begin{array}{l}\text { Vindt u dat de warme maaltijd die u heeft } \\
\text { gegeten: }\end{array}$ & Vrijwaard & Den Koogh & \\
Veel groenten bevatte & $4,5(\mathrm{~N}=41)$ & $4,6(\mathrm{~N}=37)$ & $4,7(\mathrm{~N}=91)$ \\
\hline Veel fruit bevatte (het dessert) & $1,4(\mathrm{~N}=41)$ & $3,5(\mathrm{~N}=30)$ & $3,0(\mathrm{~N}=81)$ \\
\hline Verse groenten bevatte & $4,5(\mathrm{~N}=33)$ & $4,7(\mathrm{~N}=30)$ & $4,8(\mathrm{~N}=77)$ \\
\hline Vers fruit bevatte (het dessert) & $2,8(\mathrm{~N}=21)$ & $4,1(\mathrm{~N}=24)$ & $4,5(\mathrm{~N}=65)$
\end{tabular}

Tabel B4.9 Behoefte aan meer groenten onder de cliënten van Omring $(N=91)$

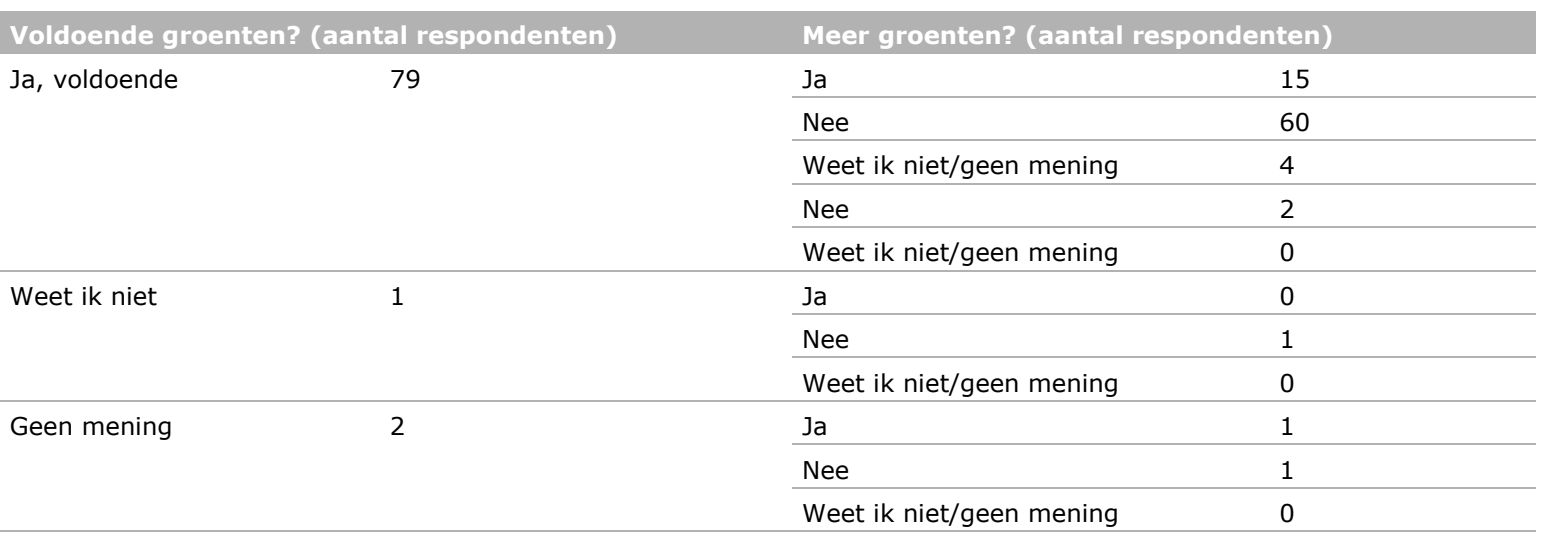

Tabel B4.10 Redenen om meer of minder groenten te willen onder de cliënten bij Omring $(N=85)$, in procent

\begin{tabular}{llll} 
Behoefte aan meer groenten omdat... $(\mathrm{N}=24)$ & \multicolumn{3}{l}{ Behoefte aan minder groenten omdat... (N=61) } \\
Gezond & 46 & Kan niet meer op & 92 \\
\hline Lekker & 46 & Houdt niet van groente & 5 \\
\hline Overig & 8 & Overig & 3 \\
\hline Totaal & 100 & Totaal & 100 \\
\hline
\end{tabular}


Tabel B4.11 Nieuwe ideeën om (meer) groenten aan te bieden

\begin{tabular}{|c|c|}
\hline Idee & Opmerkingen/ toelichting \\
\hline $\begin{array}{l}\text { Vergeten groenten } \\
\text { Sommige deelnemers positief, anderen } \\
\text { terughoudender }\end{array}$ & $\begin{array}{l}\text { - Verschil van inzicht of de cliënten dit wel of niet kennen. } \\
\text { - Dat kent mijn moeder niet } \\
\text { - We hebben een proeverij gehad met cliënten } 1.5 \text { jaar geleden op basis daarvan } \\
\text { is menu van de chef mede bepaald en ook de keuze voor aardappelras } \\
\text { - Iets voor de jongere generatie (van 50-60 jaar) } \\
\text { - Cliënten zijn niet geïnteresseerd in extra informatie of uitleg over de vergeten } \\
\text { groenten }\end{array}$ \\
\hline $\begin{array}{l}\text { Streekeigen product } \\
\text { Scoort hoog }\end{array}$ & $\begin{array}{l}\text { - Dit wordt vermeld op de menukaart (als de cliënten de keuze voor het eten } \\
\text { maken) } \\
\text { - Is bekend, spreekt aan } \\
\text { - Dat komt uit de buurt } \\
\text { - Witlof uit Breezand gaat beter dan 'gewoon' witlof } \\
\text { - Vlees van slagerij X } \\
\text { - Vis van visboer Y } \\
\text { - Staat voor kwaliteit }\end{array}$ \\
\hline $\begin{array}{l}\text { Wrap, broccoli drankje } \\
\text { Scoort laag }\end{array}$ & $\begin{array}{l}\text { - Wat de boer niet kent eet hij niet } \\
\text { - Hanteerbaarheid is lastig, moet gesneden worden (wrap) } \\
\text { - Onhandig om te eten }\end{array}$ \\
\hline $\begin{array}{l}\text { Soep met groenten } \\
\text { Scoort hoog }\end{array}$ & $\begin{array}{l}\text { - Er wordt nu elke dag verse soep gemaakt } \\
\text { - Geschikt om veel groente in te verwerken }\end{array}$ \\
\hline $\begin{array}{l}\text { Bordje met tomaten } \\
\text { Sommigen positief, anderen } \\
\text { terughoudender }\end{array}$ & - Leuk om eens te proberen \\
\hline
\end{tabular}

Tabel B4.12 Behoefte aan meer fruit onder de cliënten van Omring $(N=89)$

\begin{tabular}{|c|c|c|c|}
\hline \multicolumn{2}{|c|}{ Voldoende fruit? (aantal respondenten) } & \multicolumn{2}{|c|}{ Wilt u meer fruit? (aantal respondenten) } \\
\hline \multirow[t]{2}{*}{ Ja, voldoende } & \multirow[t]{2}{*}{55} & $\mathrm{Ja}$ & 16 \\
\hline & & Nee & 38 \\
\hline \multirow[t]{2}{*}{ Nee, onvoldoende } & \multirow[t]{2}{*}{32} & $\mathrm{Ja}$ & 28 \\
\hline & & Nee & 3 \\
\hline \multirow[t]{3}{*}{ Weet ik niet } & \multirow[t]{3}{*}{0} & $\mathrm{Ja}$ & 0 \\
\hline & & Nee & 0 \\
\hline & & Weet ik niet/geen mening & 0 \\
\hline Geen mening & 2 & $\mathrm{Ja}$ & 0 \\
\hline
\end{tabular}

Tabel B4.13 Voorkeur voor moment(en) en vorm(en) van meer groenten bij cliënten van de Stichting Omring, $n=67$ (meerdere antwoorden per respondent mogelijk), in aantal antwoorden

\begin{tabular}{|c|c|c|c|c|c|c|c|}
\hline & Soep & Salade & Rauwkost & Smoothie & $\begin{array}{l}\text { Gekookte } \\
\text { groenten }\end{array}$ & Overig & Totaal \\
\hline Ontbijt & & & & 1 & & & 1 \\
\hline Warme maaltijd & 22 & 24 & 29 & 8 & 43 & 8 & 134 \\
\hline Broodmaaltijd & 1 & 1 & 2 & 2 & & 1 & 7 \\
\hline
\end{tabular}


Tabel B4.14 Redenen om meer of minder fruit onder de cliënten bij Omring te willen $(N=81)$, in procent

\begin{tabular}{llll} 
Behoefte aan meer omdat... $(\mathrm{N}=44)$ & \multicolumn{1}{l}{ Behoefte aan minder omdat... (N=37) } \\
Gezond & 57 & Kan niet meer op & 54 \\
\hline Lekker & 29 & Heeft zelf fruit & 32 \\
\hline Gezond en lekker & 14 & Houdt niet van fruit & 8 \\
\hline & & Overig & 5 \\
\hline Totaal & 100 & Totaal & 100
\end{tabular}

Tabel B4.15 Voorkeur voor moment(en) en vorm(en) van meer fruit bij cliënten van de Stichting Omring, $n=73$ (meerdere antwoorden per respondent mogelijk), in aantal antwoorden

\begin{tabular}{|c|c|c|c|c|c|c|}
\hline & $\begin{array}{l}\text { Fruitsap } \\
\text { automaat }\end{array}$ & Fruitsap & Smoothie & Stuk fruit & Overig & Totaal \\
\hline Ontbijt & 0 & 13 & 2 & 16 & 1 & 32 \\
\hline Warme maaltijd & 0 & 8 & 1 & 11 & 1 & 21 \\
\hline Warme maaltijd - dessert & 3 & 7 & 4 & 24 & 4 & 42 \\
\hline Totaal & 5 & 41 & 13 & 118 & 10 & 187 \\
\hline
\end{tabular}

Tabel B4.16 Nieuwe ideeën om (meer) fruit aan te bieden

\begin{tabular}{ll} 
Idee & Opmerkingen/ toelichting \\
Smoothies & Smoothies van framboos en aardbeien worden gewaardeerd \\
\hline Geraspt, geschild fruit & \\
\hline Zacht fruit & Banaan, druiven \\
\hline
\end{tabular}

Tabel B4.17 Belang dat cliënten van Stichting Vrijwaard en Stichting Omring (locatie Den Koogh) in 2015 hechten aan over regionale herkomst van hun voedsel en de informatie daarover; 1 = helemaal niet belangrijk; 5 = heel belangrijk

\begin{tabular}{lll} 
Wat is belangrijk voor u aan de warme maaltijd? & Vrijwaard & Den Koogh \\
Veel producten uit Noord-Holland & $2,2(\mathrm{~N}=39)$ & $2,2(\mathrm{~N}=37)$ \\
\hline Voldoende informatie over de achtergrond van het eten & $2,8(\mathrm{~N}=39)$ & $2,3(\mathrm{~N}=36)$ \\
\hline
\end{tabular}

Tabel B4.18 Tevredenheid van de cliënten van Stichting Vrijwaard (2015) en Stichting Omring (2016) over regionale herkomst van hun voedsel en de informatie daarover; 1 = helemaal niet tevreden; 5 = heel tevreden

\begin{tabular}{llll} 
Vindt u dat de warme maaltijd die u heeft gegeten: & Vrijwaard & Den Koogh & Omring \\
Veel producten uit Noord-Holland bevatte & $4,2(\mathrm{~N}=20)$ & $3,7(\mathrm{~N}=3)$ & $4,5(\mathrm{~N}=42)$ \\
\hline Voldoende informatie over de achtergrond van het eten bevatten & $2,2(\mathrm{~N}=40)$ & $1,7(\mathrm{~N}=34)$ & $2,4(\mathrm{~N}=83)$ \\
\hline
\end{tabular}

Er is overigens ook grote tevredenheid over de maaltijd als geheel, zie bijlage 4. 
Tabel B4.19 Aandeel cliënten die het streekmenu makkelijk, aantrekkelijk en normaal vindt om te kiezen, $(n=89)$, in procenten

\begin{tabular}{|c|c|c|c|c|}
\hline & $\mathrm{Ja}$ & Nee & Weet niet & $\begin{array}{l}\text { Geen } \\
\text { mening }\end{array}$ \\
\hline Makkelijk om te kiezen $(\mathrm{N}=85)$ & 36 & 2 & 42 & 20 \\
\hline 'Normaal' om te kiezen $(\mathrm{N}=88)$ & 70 & 3 & 14 & 13 \\
\hline
\end{tabular}

Tabel B4.20 Redenen waarom het streekmenu makkelijk is om te kiezen $(N=30)$

\begin{tabular}{ll} 
& Aantal cliënten \\
De smaak & 8 \\
\hline Makkelijk om aan te kruisen & 9 \\
\hline Goede aankondiging & 6 \\
\hline Weet het niet & 1 \\
\hline Overig & 6 \\
\hline
\end{tabular}

Tabel B4.21 Redenen waarom het streekmenu normaal is om te kiezen $(N=58)$

\begin{tabular}{ll} 
Smaak/kwaliteit & Aantal cliënten \\
\hline Afwisseling/variatie & 9 \\
\hline Vers/gezond & 5 \\
\hline Regionaal/uit de streek & 2 \\
\hline Sociale norm & 17 \\
\hline Weet het niet & 8 \\
\hline Overig & 5 \\
\hline
\end{tabular}

Tabel B4.22 Belang dat cliënten van Stichting Vrijwaard en Stichting Omring hechten aan biologische herkomst van hun voedsel; $1=$ helemaal niet belangrijk; $5=$ heel belangrijk

$\begin{array}{lll}\text { Wat is belangrijk voor } u \text { aan de warme maaltijd? } & \text { Vrijwaard } & \text { Den Koogh } \\ \text { Biologisch is } & 2,0(\mathrm{~N}=39) & 2,5(\mathrm{~N}=37)\end{array}$

Tabel B4.23 Tevredenheid van de cliënten van Stichting Vrijwaard en Stichting Omring over biologische herkomst van hun voedsel; $1=$ helemaal niet tevreden; $5=$ heel tevreden

\begin{tabular}{lll}
\hline Vindt $u$ dat de warme maaltijd die u heeft gegeten: & Vrijwaard & Den Koogh \\
Biologisch was & $2,1(\mathrm{~N}=7)$ & $1,3(\mathrm{~N}=4)$ \\
\hline
\end{tabular}


Wageningen Economic Research Postbus 29703

2502 LS Den Haag

T 0703358330

Ecommunications.ssg@wur.nl

www.wur.nl/economic-research

Wageningen Economic Research RAPPORT

2016-089
De missie van Wageningen University \& Research is 'To explore the potential of nature to improve the quality of life'. Binnen Wageningen University \& Research bundelen Wageningen University en gespecialiseerde onderzoeksinstituten van Stichting Wageningen Research hun krachten om bij te dragen aan de oplossing van belangrijke vragen in het domein van gezonde voeding en leefomgeving. Met ongeveer 30 vestigingen, 5.000 medewerkers en 10.000 studenten behoort Wageningen University \& Research wereldwijd tot de aansprekende kennisinstellingen binnen haar domein. De integrale benadering van de vraagstukken en de samenwerking tussen verschillende disciplines vormen het hart van de unieke Wageningen aanpak. 



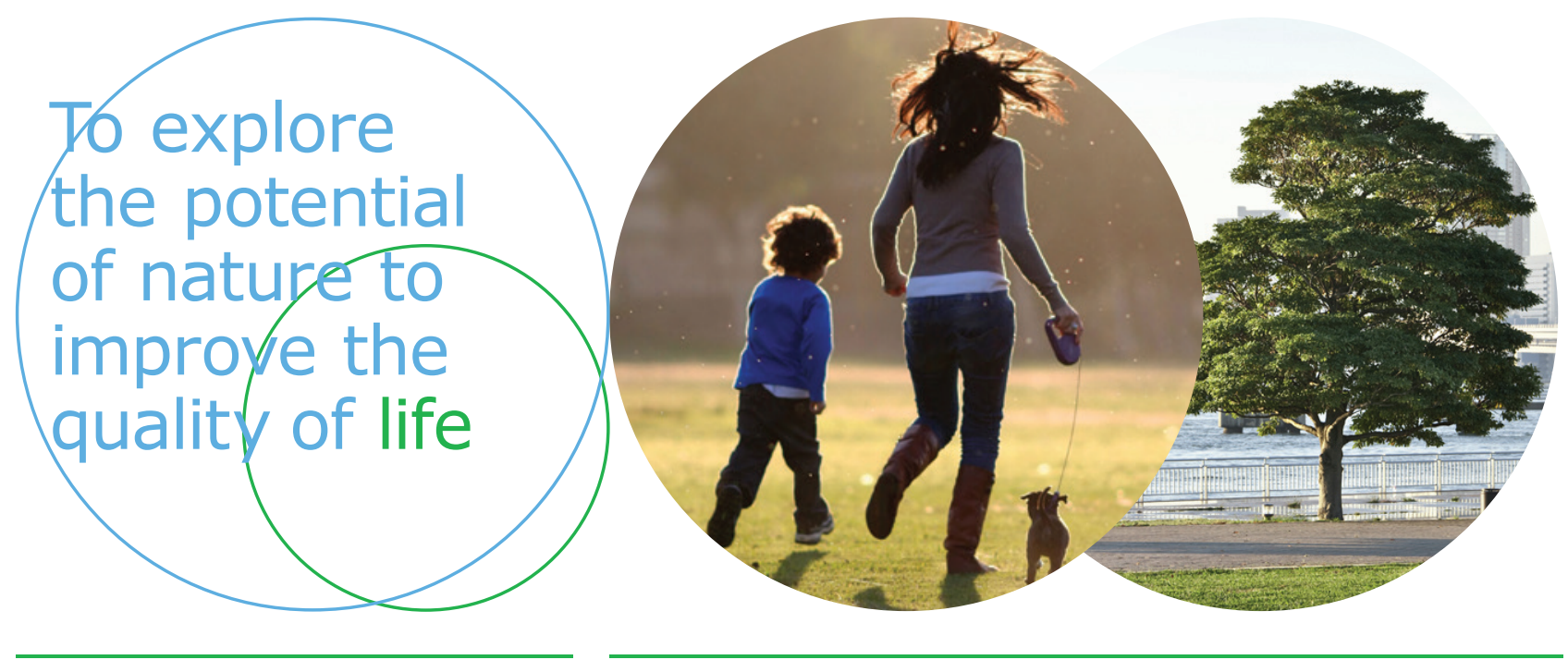

Wageningen Economic Research Postbus 29703

2502 LS Den Haag

E communications.ssg@wur.nl

$T+31(0) 703358330$

www.wur.nl/economic-research

Report 2016-089

ISBN XXXX
De missie van Wageningen University \& Research is 'To explore the potential of nature to improve the quality of life'. Binnen Wageningen University \& Research bundelen Wageningen University en gespecialiseerde onderzoeksinstituten van Stichting Wageningen Research hun krachten om bij te dragen aan de oplossing van belangrijke vragen in het domein van gezonde voeding en leefomgeving. Met ongeveer 30 vestigingen, 5.000 medewerkers en 10.000 studenten behoort Wageningen University \& Research wereldwijd tot de aansprekende kennisinstellingen binnen haar domein. De integrale benadering van de vraagstukken en de samenwerking tussen verschillende disciplines vormen het hart van de unieke Wageningen aanpak. 